\title{
Decoupling of As and Fe release to Bangladesh groundwater under reducing conditions. Part I: Evidence from sediment profiles
}

\author{
A. Horneman, ${ }^{1,2, *}$ A van Geen, ${ }^{2}$ D. V. Kent, ${ }^{2,3}$ P. E. Mathe, ${ }^{4}$ Y. Zheng, ${ }^{2,5}$ R. K. Dhar,${ }^{5}$ S. O’Connell, ${ }^{6}$ M. A. Hoque, ${ }^{7}$ \\ Z. Aziz, ${ }^{2,7}$ M. Shamsudduha, ${ }^{7}$ A. A. Seddique, ${ }^{7}$ and K. M. Ahmed ${ }^{7}$ \\ ${ }^{1}$ Department of Earth and Environmental Engineering, Columbia University, New York, New York 10027 USA \\ ${ }^{2}$ Lamont-Doherty Earth Observatory of Columbia University, Palisades, New York 10964 USA \\ ${ }^{3}$ Department of Geological Sciences, Rutgers University, Piscataway, New Jersey 08854 USA \\ ${ }^{4}$ Centre Européen de Recherche et d'Enseignement de Géosciences de l'Environnement, 13545 Aix-en-Provence, Cedex France \\ ${ }^{5}$ Queens College, City University of New York, Flushing, New York 11367 USA \\ ${ }^{6}$ Wesleyan University, Middletown, Connecticut 06459 USA \\ ${ }^{7}$ Department of Geology, Dhaka University, Dhaka Bangladesh
}

(Received September 8, 2003; accepted in revised form January 28, 2004)

\begin{abstract}
This study reexamines the notion that extensive As mobilization in anoxic groundwater of Bangladesh is intimately linked to the dissolution of Fe oxyhydroxides on the basis of analyses performed on a suite of freshly collected samples of aquifer material. Detailed sediment profiles extending to 40 to $70 \mathrm{~m}$ depth below the surface were obtained at six sites where local groundwater As concentrations were known to span a wide range. The sediment properties that were measured include (1) the proportion of Fe(II) in the Fe fraction leached in hot $1.2 \mathrm{~N} \mathrm{HCl}$, (2) diffuse spectral reflectance, and (3) magnetic susceptibility.

In parallel with local concentrations of dissolved As ranging from $<5$ to $600 \mu \mathrm{g} / \mathrm{L}, \mathrm{Fe}(\mathrm{II}) / \mathrm{Fe}$ ratios in shallow (gray) Holocene sands tended to gradually increase with depth from values of 0.3 to 0.5 to up to 0.9 . In deeper (orange) aquifers of presumed Pleistocene age that were separated from shallow sands by a clay layer and contained $<5 \mu \mathrm{g} / \mathrm{L}$ dissolved As, leachable $\mathrm{Fe}(\mathrm{II}) / \mathrm{Fe}$ ratios averaged $\sim 0.2$. There was no consistent relation between sediment $\mathrm{Fe}(\mathrm{II}) / \mathrm{Fe}$ and dissolved $\mathrm{Fe}$ concentrations in groundwater in nearby wells. The reflectance measurements indicate a systematic linear relation $\left(\mathrm{R}^{2}\right.$ of $\left.0.66 ; n=151\right)$ between the first derivative transform of the reflectance at $520 \mathrm{~nm}$ and $\mathrm{Fe}(\mathrm{II}) / \mathrm{Fe}$. The magnetic susceptibility of the shallow

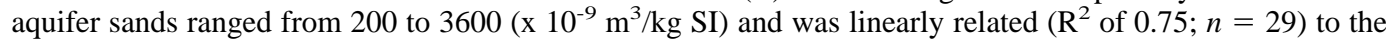
concentrations of minerals that could be magnetically separated ( 0.03 to $0.79 \%$ dry weight). No systematic depth trends in magnetic susceptibility were observed within the shallow sands, although the susceptibility of deeper low-As aquifers was low (up to $\sim 200 \times 10^{-9} \mathrm{~m}^{3} / \mathrm{kg} \mathrm{SI}$ ).

This set of observations, complemented by incubation results described in a companion paper by van Geen et al. (this volume), suggests that the release of As is linked to the transformation of predominantly Fe (III) oxyhydroxide coatings on sand particles to $\mathrm{Fe}$ (II) or mixed Fe(II/III) solid phases with a flatter reflectance spectrum such as siderite, vivianite, or magnetite, without necessarily resulting in the release of Fe to groundwater. The very low As/Fe ratio of magnetically separated minerals compared to the As/Fe of bulk acid leachate ( 2 vs. 40 $10^{-6}$, respectively) suggests that such a transformation could be accompanied by a significant redistribution of As to a mobilizable phase on the surface of aquifer particles. Copyright (C) 2004 Elsevier Ltd
\end{abstract}

\section{INTRODUCTION}

Over the past three decades millions of tube wells have been installed in the Ganges-Brahmaputra-Meghna delta to provide pathogen-free water for cooking and drinking (Smith et al., 2000; BGS and DPHE, 2001). Following the initial discovery of elevated arsenic concentrations in West Bengal, India in the mid 1980s and in Bangladesh in the mid 1990s, more extensive surveys have indicated that one-third of the existing wells in Bangladesh yield water that does not meet the local drinking water standard of $50 \mu \mathrm{g} / \mathrm{L}$ for As, and one-half do not meet the $10 \mu \mathrm{g} / \mathrm{L}$ guideline value of the World Health Organization (Dhar et al., 1997; BGS and DPHE, 2001), potentially threatening the health of millions of people (Yu et al., 2003).

Previous studies seeking to understand the mechanism of arsenic mobilization indicate that sediment iron (oxyhydr)oxide coatings are likely to play an important role in controlling As

* Author to whom correspondence should be addressed (Horneman@1deo.columbia.edu). concentrations in groundwater (Nickson et al., 1998; Nickson et al., 2000; McArthur et al., 2001). Arsenic, indeed, has a very high affinity for iron microbially driven reductive dissolution of Fe oxyhydroxides can, therefore, result in a significant transfer of As to solution (Aggett and Obrien, 1985; Peterson and Carpenter, 1986; Belzile and Tessier, 1990; Bowell, 1994; Widerlund and Ingri, 1995; Sullivan and Aller, 1996; Nickson et al., 2000; Welch et al., 2000). But the rather scattered relation between dissolved As and Fe concentrations in Bangladesh groundwater suggests that the hypothesis of congruent Fe-oxides dissolution might be an oversimplification (BGS and DPHE, 2001). One of the possibilities explored with the data presented in this study is that As may be significantly mobilized during the gradual reduction of $\mathrm{Fe}$ (III) oxyhydroxides to various $\mathrm{Fe}$ (II, III) or Fe(II) solid phases, i.e., before the process results in a significant release of $\mathrm{Fe}$ (II) to solution.

Bangladesh aquifer material typically contains fine- to medium-sized sand grains of quartz, plagioclase, feldspar, and variable amounts of mica (BGS and DPHE, 2001). The color of 


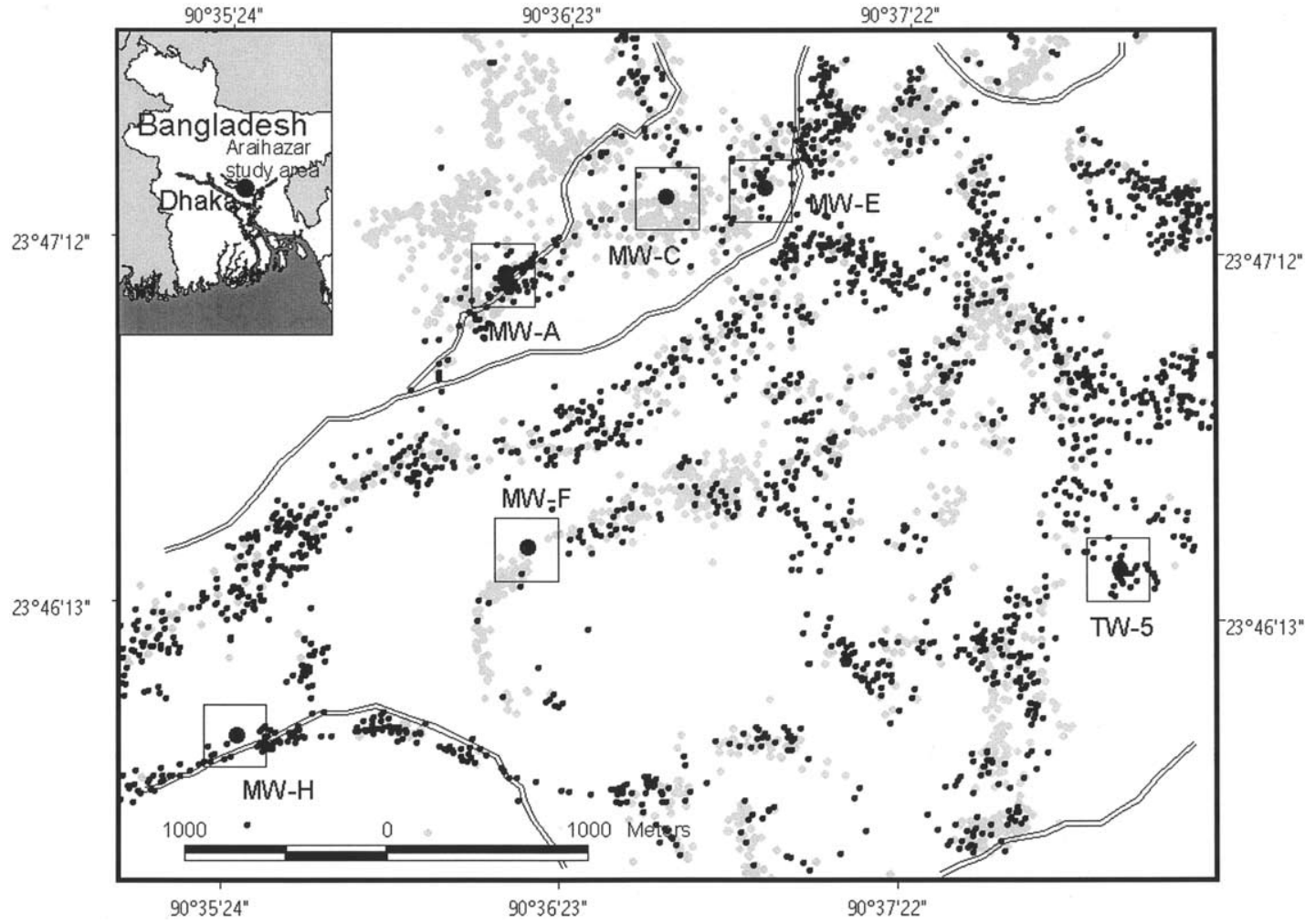

Fig. 1. Map of the study area showing the positions of multilevel wells (MW) and the test well (TW) where sediment profiles were collected. Larger streams are shown as black lines. Tube wells with As $>50 \mu \mathrm{g} / \mathrm{L}$ are shown as black dots, wells with As $\leq 50 \mu \mathrm{g} / \mathrm{L}$ as gray dots. A $0.1 \mathrm{~km}^{2}$ area representative of As concentrations in groundwater surrounding each drilling site is marked. The inset shows the location of the study area within Bangladesh.

the shallowest sediments can be tan to brown, but typically spans a spectrum of grays, and darkens with depth. The changes in color are likely to be related to the reduction of hematite and goethite coatings in the sediment. Although such changes have been linked to changes in the redox state of $\mathrm{Fe}$ in sediment elsewhere (Balsam and Deaton, 1991; Balsam and Wolhart, 1993; Giosan et al., 2002), this has, to our knowledge, not been demonstrated quantitatively for Bangladesh aquifers.

Microorganisms are typically involved in the mediation of the redox transformations of $\mathrm{Fe}$ oxyhydroxides. Laboratory experiments have shown that the microbial-driven reduction of $\mathrm{Fe}^{3+}$ can be direct through dissimilatory iron-reducing bacteria (Lovley, 1990; Caccavo et al., 1994; Lovley, 1997; Fredrickson et al., 1998; Cummings et al., 1999; Cummings et al., 2000; Lloyd et al., 2000; Niggemyer et al., 2001), or indirect through electron shuttling by humic acids (Bradley et al., 1998; Nevin and Lovley, 2002a; Nevin and Lovley 2002b). The resulting conversion of $\mathrm{Fe}(\mathrm{III})$ oxyhydroxides not only releases $\mathrm{Fe}(\mathrm{II})$ but can also produce authigenic phases such as magnetite, siderite, and green rust (Lovley, 1990; Lovley, 1997; Benner et al., 2002; Zachara et al., 2002). In an elegant set of column experiments, Benner et al. (2002) recently documented the darkening of iron oxyhydroxide coatings by microbially driven reduction as well as the conversion of the coatings to magnetite with a relatively minor loss of $\mathrm{Fe}(\mathrm{II})$ to the effluent.

The objective of the present study is to determine if a direct link can be established between groundwater As levels and any other property of the sediment. It has already been shown that the bulk As content of Bangladesh aquifers sands, which typically ranges from 2 to $10 \mu \mathrm{g} / \mathrm{g}$, is not related in any systematic way to groundwater As concentrations (BGS and DPHE, 2001; Harvey et al., 2002). Changes in the redox state of Fe oxyhydroxides, as determined from sediment reflectance and magnetic properties, are the two specific directions that are explored here. The structure of the paper is as follows: Section 2 describes the history and nature of sediment deposition in the Ganges-Brahmaputra-Meghna delta (GBMD) and relates these observations to our study area in Araihazar upazila, Bangladesh; Section 3 describes the six sampling sites and the different techniques that were used to collect the sediment and analyze the material; Section 4 compares the sediment results with groundwater As concentrations from nearby nests of monitoring wells and surrounding private wells; and Section 5 discusses the extent to which the redox state of the sediment can be used for predicting groundwater As concentrations and concludes that the magnetic susceptibility signal is dominated by a detrital component.

\section{GEOLOGIC SETTING}

Between 20 and $80 \mathrm{~m}$ of alluvial silt, sand, gravel, and clay have accumulated across GBMD over the last 5 to $7 \mathrm{kyr}$ of the Holocene (Goodbred and Kuehl, 1999; Goodbred and Kuehl, 


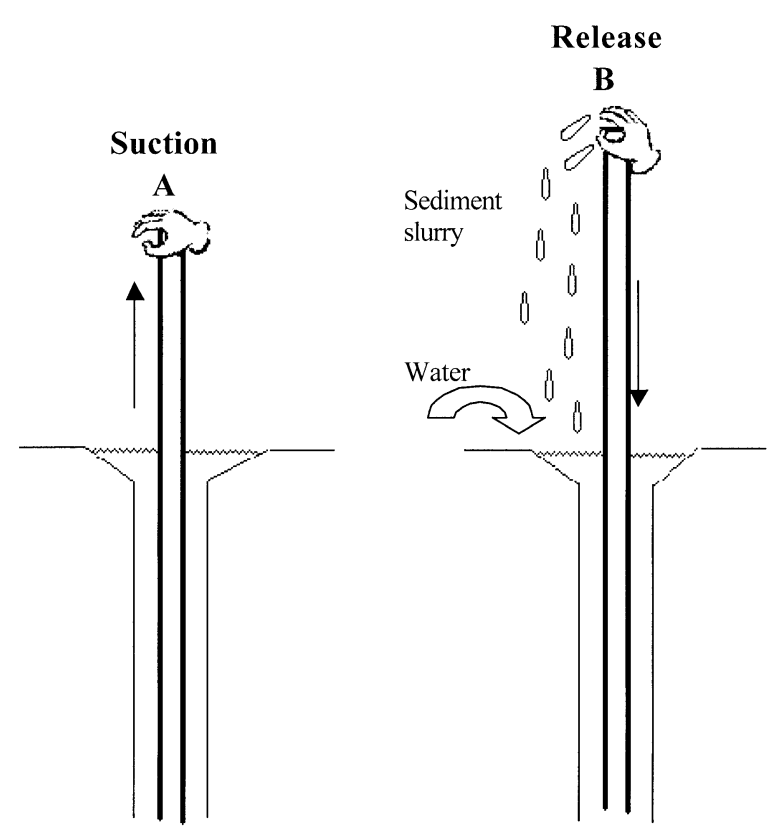

Fig. 2. Illustration of the hand-flapper drilling method. A small pond is dug, and always kept full of water. (A) Suction: The section of pipe is lifted while a hand closing the top ensures that the pipe remains filled with water; (B) Release: The pipe is dropped while the hand releases sediment slurry from the top back to the pond. Sediment cuttings are collected by allowing the slurry to settle in a separate container.

2000; BGS and DPHE, 2001; Goodbred et al., 2003). These relatively young deposits are typically distinguished by their gray color from older Pleistocene formation such as the Dupi Tila sands that are brown to orange. The geology of Araihazar upazila, the site of a long-term health, earth, and social science study (http://superfund.ciesin.columbia.edu), is relatively complex because it lies close to the Madhupur Terrace, a Pleistocene uplift to the west. The interface between Holocene and older deposits drops from a depth of $30 \mathrm{~m}$ in the western portion of Araihazar to a depth of $150 \mathrm{~m}$ within a distance of a few kilometers to the east (van Geen et al., 2003).

The study area in Araihazar is a floodplain environment located $\sim 10 \mathrm{~km}$ west of the modern course of the Meghna River. The Meghna is a high-discharge stream that drains the Sylhet Basin and surrounding hills of Assam, but its sediment load is small compared to the Ganges and Brahmaputra rivers. However, Araihazar was previously influenced by the Brahmaputra until it shifted its course by several $100 \mathrm{~km}$ to the west in the early 1800s (Fergusson, 1863).

A set of 6000 groundwater samples collected from tube wells in the area indicate that about half of the population was initially exposed to arsenic levels above $50 \mu \mathrm{g} / \mathrm{L}$ (van Geen et al., 2003). The proportion of the 6000 wells that exceed 50 $\mu \mathrm{g} / \mathrm{L}$ arsenic increases with depth from $25 \%$ between 8 and $10 \mathrm{~m}$ to $75 \%$ between 15 to $30 \mathrm{~m}$, then declines gradually to less than $10 \%$ at $90 \mathrm{~m}$. Existing private wells and installed community wells that tap into the orange-colored Pleistocene deposits provide villagers with water that typically contains less than $10 \mu \mathrm{g} / \mathrm{L}$ As (van Geen et al., 2003).

\section{MATERIAL AND METHODS}

\subsection{Site Selection}

Within the $25 \mathrm{~km}^{2}$ encompassed by the survey of 6000 wells, six contrasting sites were selected for study of the relation between groundwater arsenic and the redox state of the sediment (Fig. 1). At 5 of these sites, dissolved As and Fe data were available from nests of 3 to 5 monitoring wells, ranging between 6 and $64 \mathrm{~m}$ in depth and located within $2 \mathrm{~m}$ of the site where sediment was collected. Test well 5 (TW-5), which consisted of only one $64 \mathrm{~m}$ well, was installed in an unsuccessful attempt to reach deep orange sands at this site.

\subsection{Collection of Cuttings}

Sediment cuttings were collected in June 2001 and January 2002 from each of the six sites by relying on the indigenous method of installing wells. The so-called "hand-flapper" or "sludger" method is based on the application of suction and release, using the hand as a check valve, to a PVC pipe that is repeatedly lowered and raised to deepen a drill hole (Fig. 2). The overflowing sediment-laden water was collected at selected intervals, typically 1.5 to $3 \mathrm{~m}$, and allowed to settle

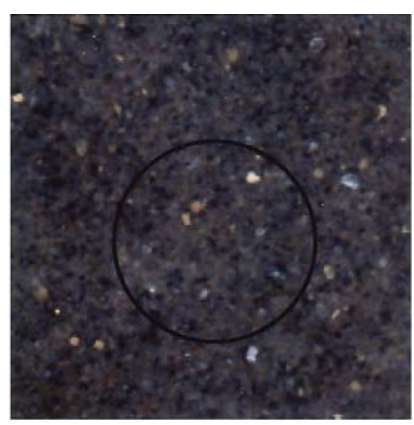

A. $\mathrm{MW}-\mathrm{F}(4.5 \mathrm{~m})$

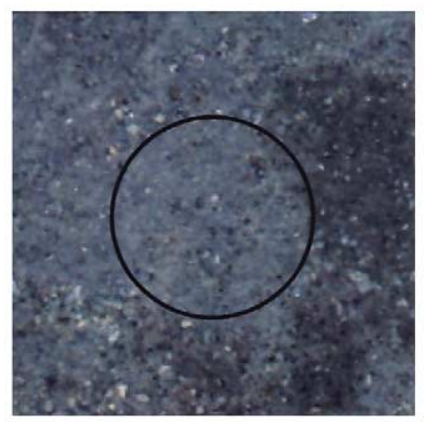

B. MW-F (30.5 m)
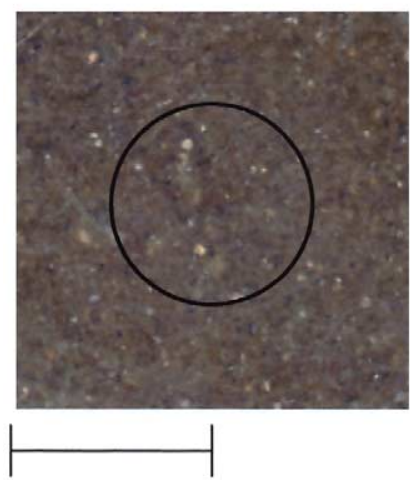

$8 \mathrm{~mm}$

Fig. 3. Examples of brown-tan (A), gray (B), and orange (C) sand from site MW-F. The circles indicate the size of the $0.8 \mathrm{~cm}$-diameter window of the reflectance spectrophotometer. 


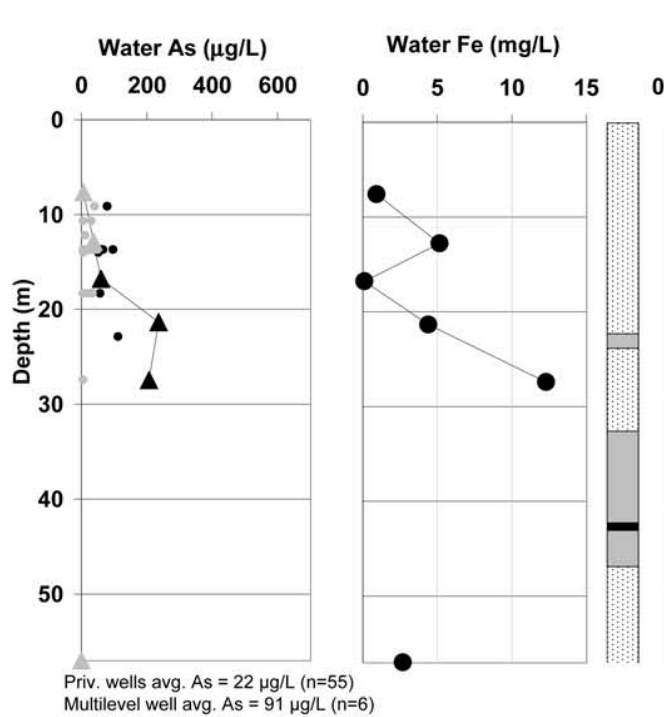

Leach. Fe II/Fe II+III

$\Delta R$ at $520 \mathrm{~nm}$

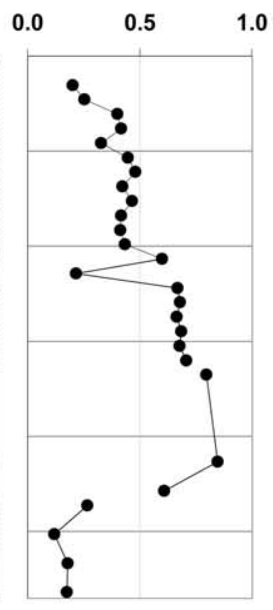

MW-C

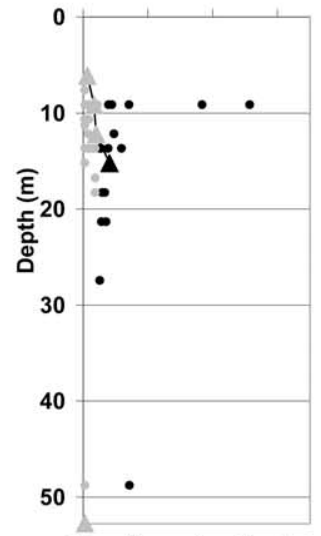

Priv. wells avg. $A s=24 \mu \mathrm{g} / \mathrm{L}(\mathrm{n}=121)$ Multilevel well avg. As $=35 \mu \mathrm{g} / \mathrm{L}(\mathrm{n}=5)$

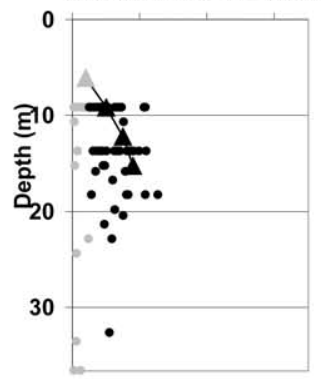

Priv. wells avg. As $=68 \mu \mathrm{g} / \mathrm{L}(\mathrm{n}=125)$ Multilevel well avg. As $=118 \mu \mathrm{g} / \mathrm{L}(\mathrm{n}=4)$
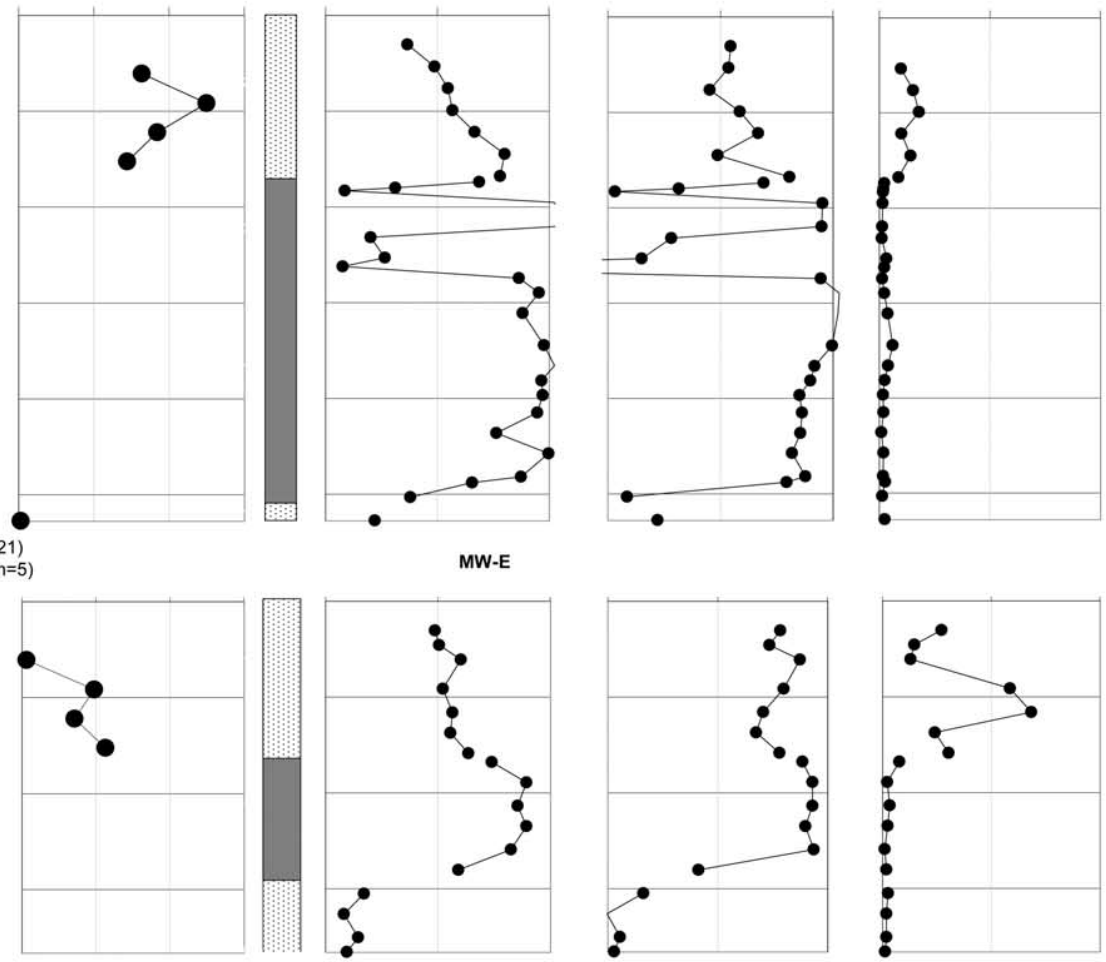

Fig. 4. (A) and (B) Groundwater and sediment properties as function of depth for the 6 study sites. From left to right (1) triangles indicate dissolved As concentration in multilevel wells, circles show As in surrounding wells within a $0.1 \mathrm{~km}^{2}$ area, black- or gray-filled symbols indicate As concentrations $>50 \mu \mathrm{g} / \mathrm{L}$ or $\leq 50 \mu \mathrm{g} / \mathrm{L}$ respectively; (2) circles indicate dissolved Fe concentration in monitoring wells; (3) basic stratigraphy of each site showing sand (light), clay (dark), and peat (black) layers; (4) Fe(II)/Fe ratio for acid-leachable fraction of the sediment; (5) first derivative transform of reflectance spectrum of the sediment $\Delta \mathrm{R}$ value at $520 \mathrm{~nm}$; and (6) magnetic susceptibility of the sediment.

for a few minutes. The sediment samples obtained in this fashion were, therefore, probably biased towards the coarse fraction. Three examples of the different types of sediment samples obtained in the area are shown in Figure 3. They include brown shallow sediment cuttings (MW-F, $4.5 \mathrm{~m}$ ), more reduced shallow gray sediment (MW-F, $30.5 \mathrm{~m}$ ), and orange deep sands (MW-F, $52 \mathrm{~m}$ ). After measurements of various properties on the day of collection, the sediment samples were stored in Zip-Lock bags.

\subsection{Reflectance Spectroscopy}

A CM 2002 spectrophotometer (Minolta Corp., USA) was used to measure the diffuse reflectance spectrum of 161 freshly collected sediment samples in the field relative to a white standard plate made of barium sulfate (Clark et al., 1993). The settings corresponded to an illuminant source of D65 (daylight-containing ultraviolet component, 

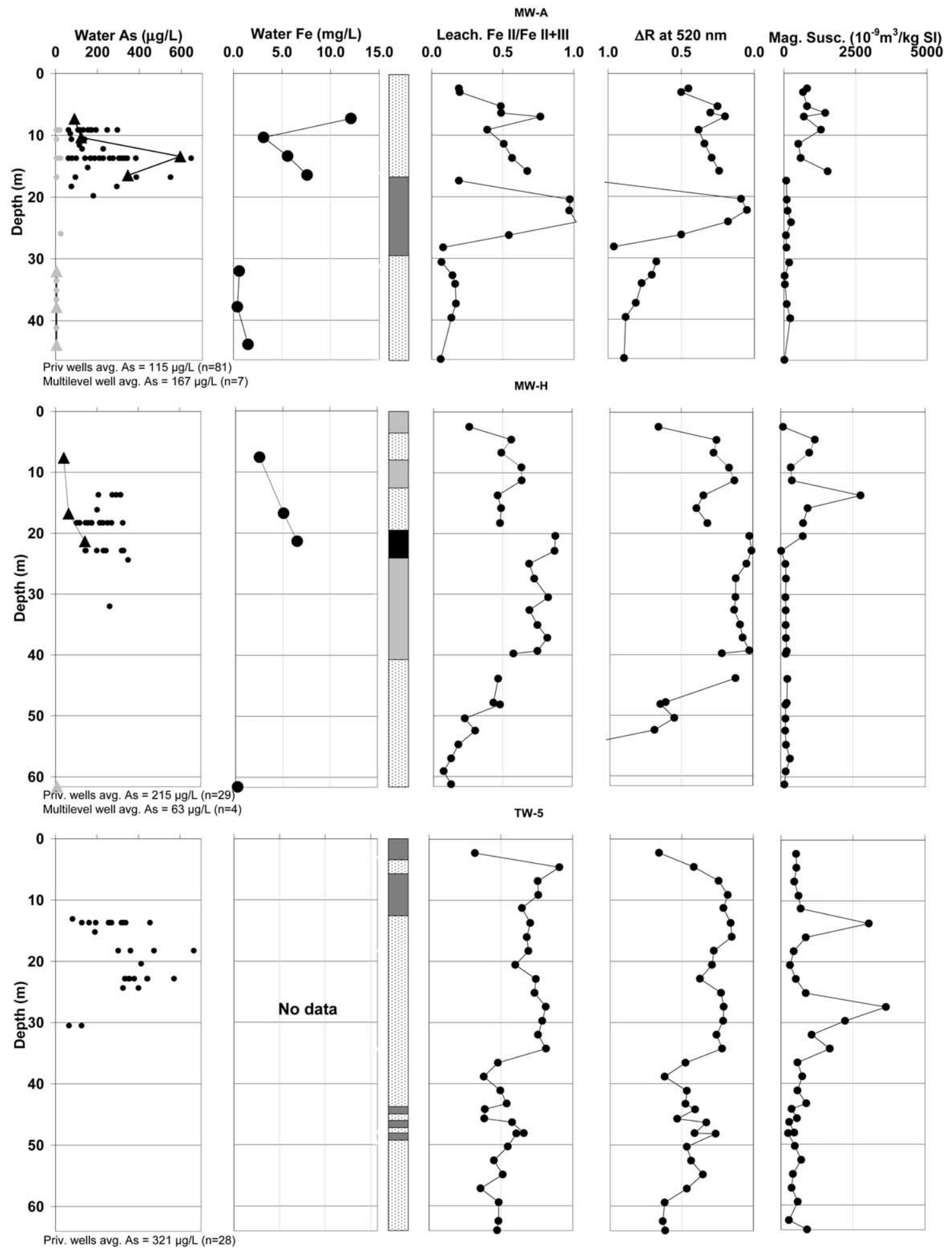

Fig. 4. (Continued)

color temperature $6504 \mathrm{~K}$ ), with the observer angle set to $10^{\circ}$, and the specular component (direct reflection) was excluded.

Sediment samples were placed in a cut $20 \mathrm{~mL}$ scintillation vial (surface diameter $1.75 \mathrm{~cm}$ ) and then covered with clear polyethylene cling-wrap $\left(\mathrm{Glad}^{\circledR}, \mathrm{USA}\right)$. Each reading is the average of a sequence of three measurements made automatically without moving the instru- ment. Three such averaged readings were collected, then the sediment was mixed and another 3 readings obtained. The sequence was then repeated a third time. The reflectance values discussed in this paper are, therefore, based on a total of 9 readings. Before analyzing each sample, the white standard was remeasured. Instrument drift remained below $\pm 0.01 \%$ per measurement across the entire spectrum. Reflectance 
measurements were conducted a second time on a subset of 43 sediment samples four weeks after collection. Reflectance spectra were compared for a subset of samples before and after dark micaceous minerals were removed by hand under microscope.

\subsection{Separation of Magnetic Minerals}

Magnetic minerals were collected in the field by making sediment slurries from $\sim 20 \mathrm{~cm}^{3}$ of sediment cuttings. This was done by placing a magnet inside the finger cut from a plastic glove and using it to stir the slurry. The mass of the original sediment slurry was measured in the field on a portable scale. The wet sediment typically contained 15 to $25 \%$ water, which results in an uncertainty in the calculated dry mass of 8 to $14 \%$. The collected magnetic minerals were brought back to the lab, dried, and their mass $(0.008-0.792 \mathrm{~g})$ was measured with a microbalance.

\subsection{Iron Leaching and Speciation}

\subsubsection{Hot Hcl leach}

A hot $\mathrm{HCl}$ leach was selected to leach amorphous and relatively labile crystalline $\mathrm{Fe}$ oxyhydroxides phases. Approximately $50 \mathrm{mg}$ of wet sediment was placed in a $20 \mathrm{~mL}$ scintillation vial in the field soon after collection. On the evening of each day samples were collected, 10 $\mathrm{mL}$ of $1.2 \mathrm{~mol} / \mathrm{L} \mathrm{HCl}$ was added to the vial, and the sediment was leached by placing the vials in a hot bath $\left(\sim 80^{\circ} \mathrm{C}\right)$ for $30 \mathrm{~min}$. After shaking the sample and letting the sediment settle, $10 \mu \mathrm{L}$ aliquots were added to a $1 \% \mathrm{HCl}$ solution containing $0.1 \mathrm{~g}$ of Ferrozine $/ \mathrm{L}$ and buffered to $\mathrm{pH} \sim 5$ with acetic acid and ammonia. Another $10 \mu \mathrm{L}$ aliquot of leachate was added to the same solution containing, in addition, $2 \mathrm{~g} / \mathrm{L}$ of the reductant hydroxylamine hydrochloride. Fe speciation was determined by comparing blank-corrected absorbance readings at $560 \mathrm{~nm}$ using a Hach 890 portable spectrophotometer for the reduced and unreduced leachate solutions (Viollier et al., 2000).

\subsubsection{Reductive leach}

To determine the background reflectance of the sediment without iron oxyhydroxide coatings, a subset of 4 samples underwent the reductive dissolution procedure of Lord (1982). The samples were leached in $1.2 \mathrm{~mol} / \mathrm{L} \mathrm{HCl}$ at $80^{\circ} \mathrm{C}$ while adding $0.25 \mathrm{~g}$ sodium dithionite every $10 \mathrm{~min}$ for $40 \mathrm{~min}$.

\subsubsection{Aqua Regia dissolution}

The sediment fraction that was magnetically separated did not dissolve in hot $\mathrm{HCl}$. To determine its composition, samples of magnetically separated minerals from Site $\mathrm{E}$ and $\mathrm{F}$ were resuspended in Aqua Regia (1:1 full strength HCl-nitric acid solution; Optima, Fisherbrand $^{\circledR}$ ) for $5 \mathrm{~h}$ at $80^{\circ} \mathrm{C}$. A small amount of residue remained at the end of the treatment, although these were not attracted by a magnet, and therefore, probably contained silicate impurities. The acid solutions were gently evaporated to dryness in a hot bath and reconstituted in 0.5 $\mathrm{mL} 10 \% \mathrm{HCl}$.

\subsection{Magnetic Susceptibility}

Within about a month of collection, a portion of the sediment samples was placed in cubical polystyrene boxes (ASC Scientific, model SBM 5111) and the net weight was measured. The susceptibility (Evans and Heller, 2003) of the wet samples from site MW-C, MW-E, MW-F, and MW-H was measured at Lamont-Doherty Earth Observatory (LDEO) with a Bartington MS2B, USA instrument; samples from TW-5, MW-A, and replicate samples from site MW-C were measured at Centre Européen de Recherche et d'Enseignement de Géosciences de l'Environnement (CEREGE) using a Kappabridge KLY-2 a.c. instrument. The results were converted from bulk normalized SI units to mass specific SI units $\left(\mathrm{kg} / \mathrm{m}^{3}\right)$, by drying the sediment and calculating the density. Samples from TW-5 were also dried at $60^{\circ} \mathrm{C}$ and reanalyzed to determine if the magnetic phases were sensitive to the temperature change.

\subsection{Arsenic and Iron Analyses in the Laboratory}

Arsenic concentrations in groundwater were measured by graphitefurnace absorption spectrometry (Hitachi Z-8200) by diluting samples $1: 5$ in a $2 \%$ by volume $\mathrm{HNO}_{3}$ solution amended with a Ni-based matrix modifier. The detection limit of the method corresponds to $\sim 5 \mu \mathrm{g} / \mathrm{L}$ in the undiluted sample (van Geen et al., 2003). Dissolved iron concentrations were determined on the same instrument by flame atomic absorption with Zeeman background correction. Groundwater samples were diluted $1: 5$ in $1.2 \mathrm{~mol} / \mathrm{L} \mathrm{HCl}$. The reconstituted acid solutions obtained by dissolving the magnetically separated minerals were analyzed for As and $\mathrm{Fe}$ by atomic absorption. After addition of the $\mathrm{Ni}$ matrix modifier, the leachates were analyzed at full strength for As. Standard additions performed on a subset of samples indicated no significant matrix effect. Iron concentrations in the leachates were analyzed by flame atomic absorption after dilution to $1: 750$ in $10 \% \mathrm{HCl}$ to bring the concentrations within the linear range of the instrument $(1-8 \mathrm{mg} / \mathrm{L})$.

\subsection{SEM/EDX Analysis of Magnetic Minerals}

In an attempt to identify authigenic magnetite, a subset of the magnetically separated minerals was analyzed by Scanning Electron Microscopy (SEM) and Energy-dispersive X-ray analyzer (EDX) (Cambridge $250 \mathrm{SEM} /$ Kevex $8000 \mathrm{EDX}$ ) at LDEO. A total of 4 samples collected from the shallow sediments at site MW-F and MW-E were examined, two samples from each site.

\section{RESULTS}

\subsection{Groundwater Arsenic and Local Stratigraphy}

At all sites but one, shallow aquifers containing brown to gray sediments are separated from deeper orange sediments by one or several clay layers (Fig. 4). In the northern and western portion of the study area (MW-A, MW-C, MW-E, and MW-H), clay layers were encountered at $\sim 15 \mathrm{~m}$ depth. At one centrally located site (MW-F), the depth to the clay layer was $30 \mathrm{~m}$. Further east at TW-5, no orange-brown sediment was observed within the $64 \mathrm{~m}$ section that was drilled, although it was subsequently encountered at this location by drilling to $\sim 150 \mathrm{~m}$ (van Geen et al., 2003). The color of the sediment within the shallow aquifers typically changed from tan to brown near the surface to darker gray at depth. None of the shallow sands were as intensely orange-brown as the deeper aquifer material. The thickness of the clay layer separating the two contrasting types of aquifers ranged from $14 \mathrm{~m}$ at MW-F and MW-E to $30 \mathrm{~m}$ at MW-C. Several thinner clay layers were also encountered within the shallow aquifers at sites TW-5, MW-F, and MW-H. The clay layers, consisting of varying proportions of silt (4-63 $\mu \mathrm{m})$ and clay $(<4 \mu \mathrm{m})$, usually were gray to green in color, although some also contained contrasting orange clays or thin $(<10 \mathrm{~cm})$ black organic-rich peat layers (Fig. 4$)$.

Groundwater As concentrations in the monitoring wells that tap into Holocene sediment range from $6 \mu \mathrm{g} / \mathrm{L}(8 \mathrm{~m}$ at Site MW-F; Fig. 4A) to $600 \mu \mathrm{g} / \mathrm{L}$ (13.5 m at Site MW-A; Fig. 4B). The average As concentration for each site, determined on the basis of samples collected from 29 to 125 existing private wells located within a $0.1 \mathrm{~km}^{2}$ area centered on each well, ranges from $20 \pm 26$ to $320 \pm 140 \mu \mathrm{g} / \mathrm{L}$ (Table 1 ).

Arsenic concentrations gradually increase with depth at most sites; concentrations exceeding $50 \mu \mathrm{g} / \mathrm{L}$ are generally encountered shallower at the sites with a higher average As concentration in surrounding wells. A general increase in As concentrations with depth that parallels the trends in the monitoring wells is also observed in the surrounding wells, although there 
Table 1. Overview of the multilevel wells and test well, ordered according to average As in surrounding privately installed wells. Also shown are GPS coordinates, number of surrounding wells, maximum and minimum As concentrations, and depth intervals of installed multilevel and test wells.

\begin{tabular}{lcccccc}
\hline Site & LAT & LONG & $\begin{array}{c}\text { \# of surrounding } \\
\text { priv. wells }\end{array}$ & $\begin{array}{c}\text { Avg. As } \\
\text { [ug/L] }\end{array}$ & $\begin{array}{c}\text { Max-min } \\
\text { As conc. } \\
\text { [ug/L] }\end{array}$ & $\begin{array}{c}\text { Depth of monitoring wells } \\
{[\mathrm{m}]}\end{array}$ \\
\hline MW-F & 23.78955 & 90.61113 & 55 & 22 & $5-237$ & $7.5,13,17,21,27.5 \& 44$ \\
MW-C & 23.78602 & 90.60338 & 121 & 24 & $5-515$ & $6,9,12,15 \& 53.5$ \\
MW-E & 23.77370 & 90.60469 & 125 & 68 & $5-254$ & $9,9,12 \& 15$ \\
MW-A & 23.78999 & 90.61588 & 81 & 115 & $5-648$ & $7.5,10.5,14,17,32,38 \& 44$ \\
MW-H & 23.76514 & 90.59074 & 29 & 215 & $7-351$ & $7.5,17,21 \& 61.5$ \\
TW-5 & 23.77315 & 90.63335 & 28 & 321 & $65-666$ & 64 \\
\hline
\end{tabular}

is considerable scatter (Fig. 4). A total of 43 private wells surrounding MW-C, MW-E, and MW-A tap into Pleistocene aquifers, based on their reported depths (verified in only a few cases) relative to the corresponding sediment sections that were recovered nearby. In all but 3 out of these 43 wells, the groundwater As concentration meets the Bangladesh drinking water standard of $50 \mu \mathrm{g} / \mathrm{L}$. For water drawn from 32 of these wells, the As concentration is below the detection limit of 5 $\mu \mathrm{g} / \mathrm{L}$ by GFAA and is consistent with the composition of water drawn from the deepest nearby monitoring wells. The exception was TW-5, that tapped into gray sediment at $64 \mathrm{~m}$ and yielded water with $90 \mu \mathrm{g} / \mathrm{L}$ As until it was reinstalled to a greater depth.

Dissolved Fe concentrations in groundwater from the shallow monitoring wells also typically increase with depth, although with considerable scatter (Fig. 4). Fe concentrations span the range of $0.3(6 \mathrm{~m}$ at MW-E) to $12.5 \mathrm{mg} / \mathrm{L}(9 \mathrm{~m}$ at MW-C). There is no systematic trend in dissolved Fe concentrations related to the ranking of the six sites in terms of the average As content of surrounding wells. There also is no evident relationship between dissolved As and Fe concentrations when considering all the monitoring well samples, although the lowest As concentrations were found in those samples containing less than $3 \mathrm{mg} / \mathrm{L} \mathrm{Fe}$ (Fig. 5A).

\subsection{Oxidation State of the Leachable Iron Fraction}

The proportion of leachable $\mathrm{Fe}(\mathrm{II}) / \mathrm{Fe}$ in the sediment measured at the six sites varied between 0.05 and 0.9 (Fig. 4). Within the shallow aquifer, the $\mathrm{Fe}(\mathrm{II}) / \mathrm{Fe}$ ratios varied over a somewhat narrower range of 0.2 to 0.8 . Particularly at the sites with relatively low average As concentrations in surrounding wells (MW-F, MW-C, and MW-E), leachable Fe(II)/Fe ratios increased steadily with depth. In the sections surrounded by the highest groundwater As concentrations, $\mathrm{Fe}(\mathrm{II}) / \mathrm{Fe}$ exceeded 0.5 within only $4.5 \mathrm{~m}$ of the surface. The strongest variability in the redox state of the sediment over short vertical distances was observed in the clay layers, with $\mathrm{Fe}(\mathrm{II}) / \mathrm{Fe}$ ratios ranging from 0.05 in orange clays to 0.98 in peat layers, and from 0.6 to 0.9 in green to gray clays. The less reducing state of the deeper Pleistocene sandy aquifers was confirmed by $\mathrm{Fe}(\mathrm{II}) / \mathrm{Fe}$ ratios around 0.2 to 0.3 , with slightly higher ratios just below the clay layers, particularly at MW-H (Fig. 4B).

For sediment intervals with $\mathrm{Fe}(\mathrm{II}) / \mathrm{Fe}$ ratios below 0.4 , none of the monitoring wells screened within a depth of $1.5 \mathrm{~m}$ from the sediment samples yielded water containing more than 10 $\mu \mathrm{g} / \mathrm{L}$ As (Fig. 5B). Sediment with a leachable Fe(II)/Fe ratio between 0.3 to 0.4 already appear gray in color, however. A total of 25 out of 46 samples in that category were from shallow Holocene aquifers, all the other samples with relatively low $\mathrm{Fe}(\mathrm{II}) / \mathrm{Fe}$ ratios were from the deeper aquifers. Above a $\mathrm{Fe}(\mathrm{II}) / \mathrm{Fe}$ ratio of 0.4 , there is no evident relationship with groundwater As concentrations vary from 50 to $600 \mu \mathrm{g} / \mathrm{L}$ (Fig. 5B).

\subsection{Diffuse Spectral Reflectance}

Not surprisingly, the reflectance of orange-brown sediment in the 600 to $700 \mathrm{~nm}$ range of wavelengths is considerably higher than in the 400 to $500 \mathrm{~nm}$ range. The reflectance spectrum of gray sediment is much flatter (Fig. 6A). Replicate measurements of reflectance of the sediment showed some variability, especially after a sample was mixed and analyzed again. However, the first derivative transform of the reflectance spectrum is very reproducible (Fig. 6B). This transformation, obtained by subtracting the $\%$ reflectance for two adjacent 10 $\mathrm{nm}$ windows in wavelength, is hereon referred to as $\Delta \mathrm{R}$ and used to characterize the reflectance spectrum of the sediment. The orange sediment from the deeper aquifer (e.g., MW-F $52 \mathrm{~m}$ ) shows a very distinctive peak with a $\Delta \mathrm{R}$ value of 0.9 at $550 \mathrm{~nm}$. The first derivative transform of tan sediment from the shallow aquifer (e.g., MW-F; $4.5 \mathrm{~m}$ ) shows a smaller peak in $\Delta \mathrm{R}$ of $\sim 0.5$ centered on a slightly lower wavelength of $520 \mathrm{~nm}$. The $\Delta \mathrm{R}$ value at $520 \mathrm{~nm}$ for gray sediment from MW-F (30.5 $\mathrm{m})$ is only 0.1 .

Exposure of the sediment to air considerably altered the reflectance spectrum over time. A sample from MW-H at $18 \mathrm{~m}$ was reanalyzed one month after collection and showed a considerable increase in $\Delta \mathrm{R}$ at $520 \mathrm{~nm}$ value from 0.3 to 0.5 (Fig. $6 \mathrm{C})$. Sediment reflectance does not seem very sensitive to the presence of micaceous black minerals, on the other hand (Fig. $6 \mathrm{D})$. There is little difference in the first derivative transform of the reflectance for measurements conducted before and after black minerals ( $\sim 2 \%$ by weight) present in the aquifer material were removed under a microscope.

The $\Delta \mathrm{R}$ values at $520 \mathrm{~nm}$ measured for sediment recovered from the six drilling sites range from close to zero in peat layers to 1.0 in orange Pleistocene sands, and between 0.1 and 0.6 in shallow sands of Holocene age (Fig. 4). There is a clear gradient from high- to low- $\Delta \mathrm{R}$ values at $520 \mathrm{~nm}$ with depth within the shallow aquifers at sites MW-F, MW-A, MW-C, and $\mathrm{TW}-5$. In contrast, $\Delta \mathrm{R}$ values start high at the shallowest sampled depth at sites MW-C and MW-E and remain constant throughout the shallow aquifers. The $\Delta \mathrm{R}$ value at $520 \mathrm{~nm}$ for the orange clay layers that were occasionally observed ap- 


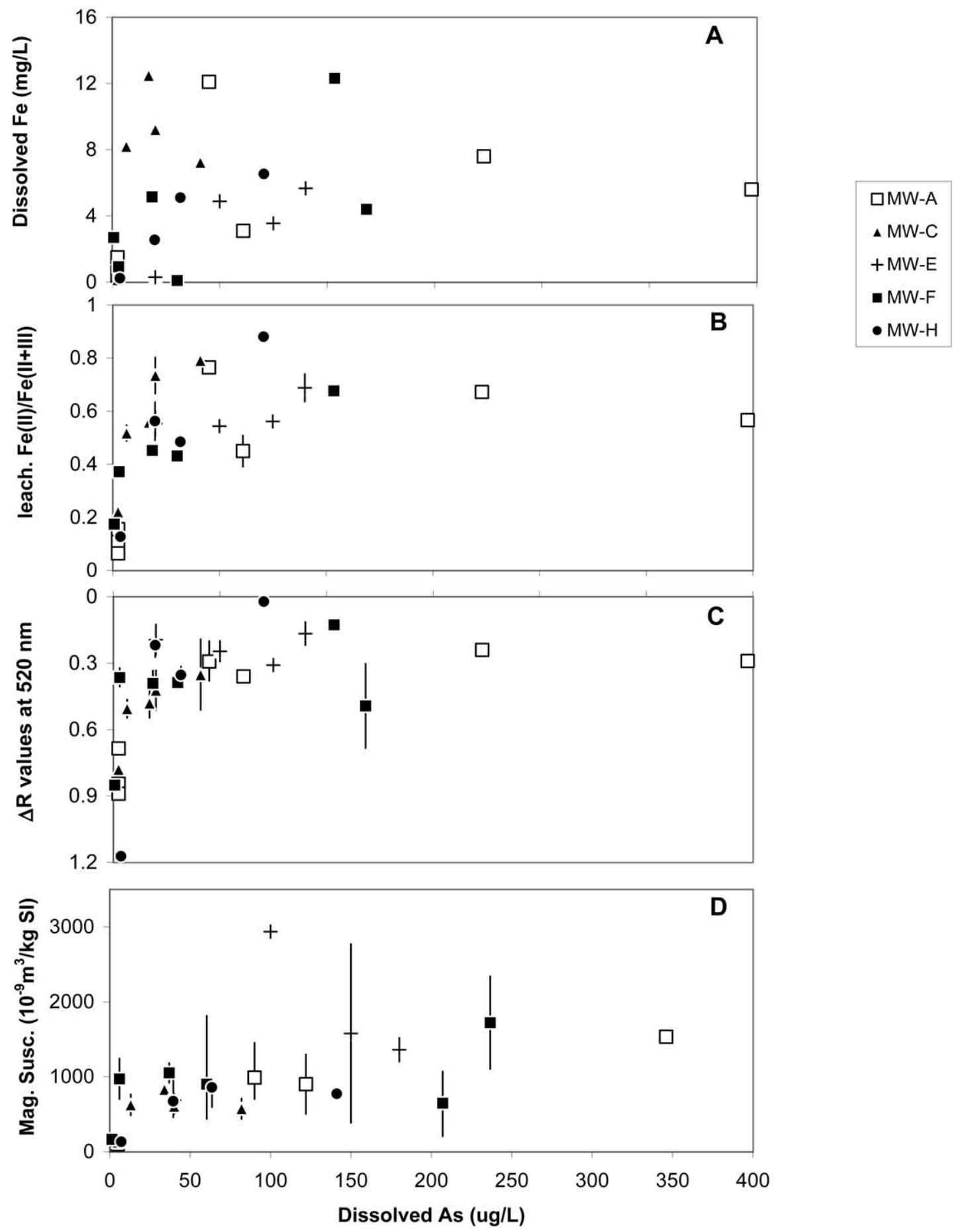

Fig. 5. (A) Comparison of dissolved As in groundwater with dissolved Fe; (B) the Fe(II)/Fe of the acid-leachable fraction of the sediment; (C) $\Delta \mathrm{R}$ values at $520 \mathrm{~nm}$; and (D) magnetic susceptibility. Sediment properties, shown with error bars corresponding to on standard deviation, were averaged for samples collected within $1.5 \mathrm{~m}$ on either side of the depth of the monitoring well.

proaches 1.0, while $\Delta \mathrm{R}$ values for the more typical gray to green layers remains below 0.3 .

Comparison of leachable $\mathrm{Fe}(\mathrm{II}) / \mathrm{Fe}$ ratios and $\Delta \mathrm{R}$ values at $520 \mathrm{~nm}$ measured on a total of 151 samples shows a significant linear relationship between the two parameters with a slope of $-0.73 \pm 0.04\left(\mathrm{R}^{2}=0.66\right)$ and a $p$-value of $5.7 \times 10^{-37}$ (Fig.
7). The slope of $\sim-1$ of this relation and the similar dynamic ranges of 0 to $\sim 1$ conveniently allows one to estimate the $\Delta \mathrm{R}$ values at $520 \mathrm{~nm}$ by subtracting the $\mathrm{Fe}(\mathrm{II}) / \mathrm{Fe}$ ratio from 1 , and vice versa. With the exception of one sample, $\Delta \mathrm{R}$ values at 520 $\mathrm{nm}$ greater than 0.6 are associated with groundwater As concentrations below $10 \mu \mathrm{g} / \mathrm{L}$ (Fig. 5C). 

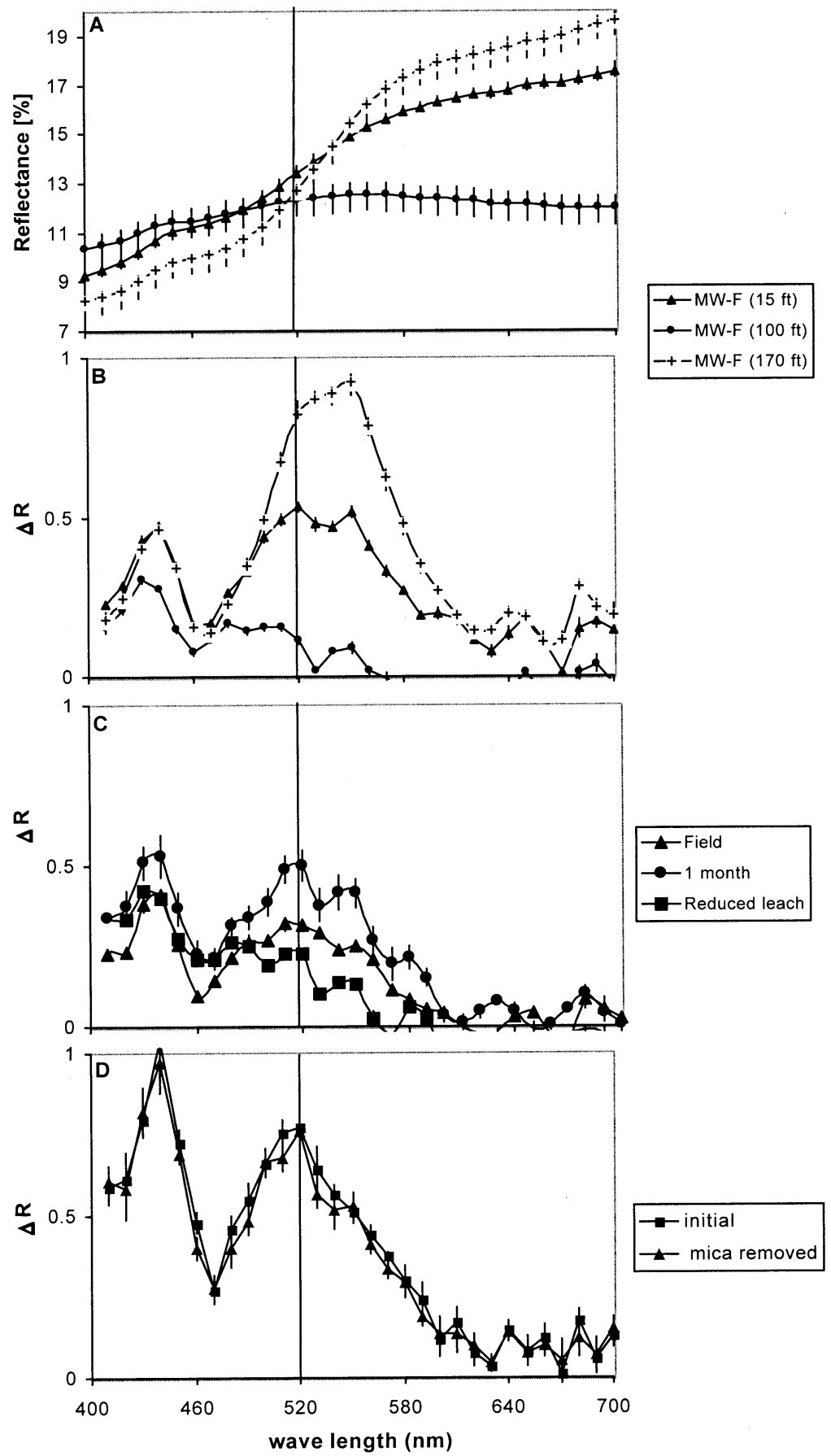

Fig. 6. (A) Diffuse spectral reflectance data for the 3 samples shown in Figure 3; (B) $\Delta \mathrm{R}$ values for the same 3 samples, with a line marking the $520 \mathrm{~nm}$ wavelength selected for this study; (C) Comparison of first derivative transform of reflectance spectrum in units of $\% / 10 \mathrm{~nm}$ wavelength interval measured immediately after sampling (field), after exposure to air for a month, and after reductive leaching; (D) Illustration of the marginal contribution of dark minerals to the reflectance spectrum of the sediment.

\subsection{Magnetic Properties}

The magnetic susceptibility of the shallow sediments is quite variable and does not show any clear trend as a function of depth (Fig. 4). Most of the measurements range between 250 and 2500 $\times 10^{-9} \mathrm{~m}^{3} / \mathrm{kg}$ SI, with a total of 5 higher values at MW-E, MW-H, and TW-5. The magnetic susceptibility of the deeper orange sediments shows much less variability and is distinctly lower $\left(<200 \times 10^{-9} \mathrm{~m}^{3} / \mathrm{k} \mathrm{SI}\right)$. There is no other obvious relation between groundwater As and magnetic susceptibility, other than the association of low As levels with deep aquifer material of lower magnetic susceptibility (Fig. 5D). 


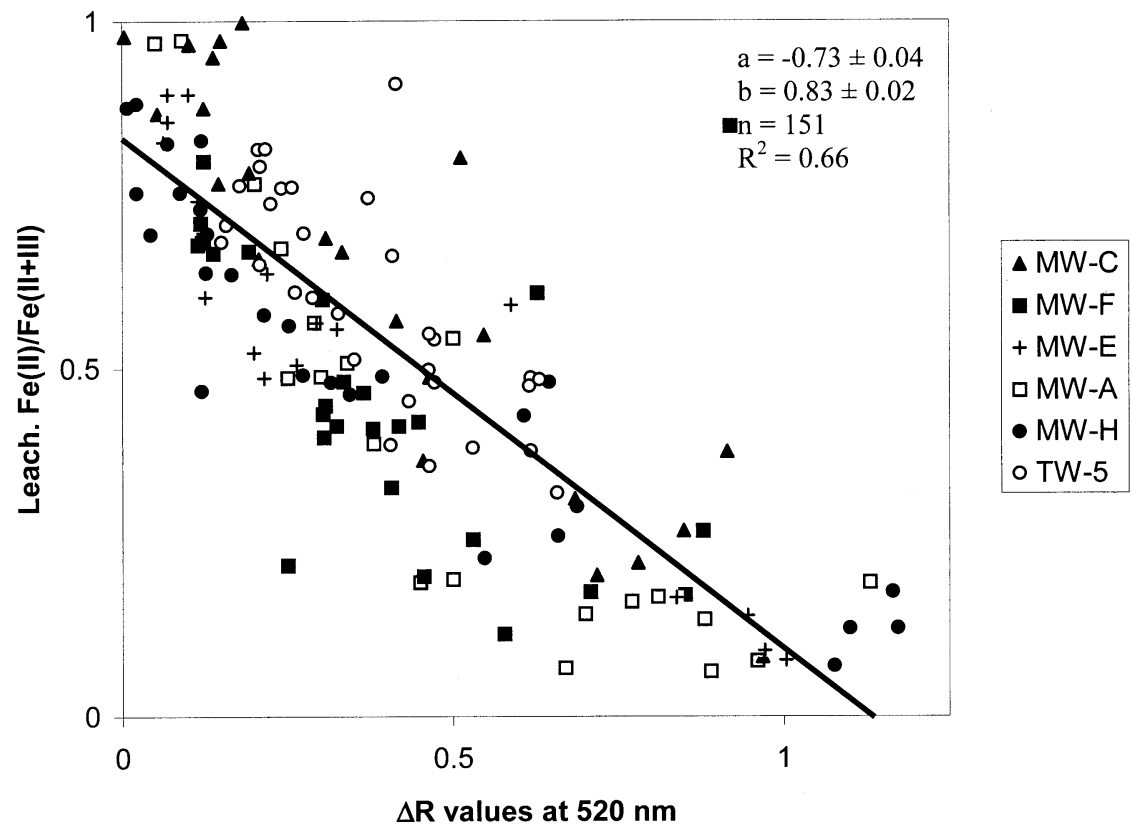

Fig. 7. Comparison of $\mathrm{Fe}(\mathrm{II}) / \mathrm{Fe}$ ratios in the acid-leachable fraction of the sediment and the first derivative transform of the reflectance spectrum $\Delta \mathrm{R}$ at $520 \mathrm{~nm}$.

The concentration of minerals separated with a magnet in the shallow aquifers at Site MW-E, MW-F, and MW-H ranges from 0 to $0.8 \mathrm{Wt} \%$. There is a significant linear relationship $\left(\mathrm{R}^{2}\right.$ of $0.75 ; n=29$ ) between the magnetic susceptibility of the bulk sediment and the concentration of magnetically separated minerals (Fig. 8). The highest concentrations of 0.5 to $0.8 \mathrm{Wt} \%$ of magnetic minerals were found in the deeper part of the shallow aquifer at sites MW-E and MW-H, and in both cases, right above the separating clay layers. Within the clay layers, the concentration of magnetic minerals was less than $0.01 \mathrm{Wt} \%$, although this may be an underestimate because the particles in the slurry did not fully disaggregate. The concentration of magnetic minerals in the orange deeper sands was consistently below $0.03 \mathrm{Wt} \%$.

Arsenic concentrations measured by dissolving the magnetic minerals ranged from 0.3 to $2.8 \mu \mathrm{g} / \mathrm{g}$ (mean of $1.0 \mu \mathrm{g} / \mathrm{g}, n=$ 17). A histogram shows that these concentrations are very

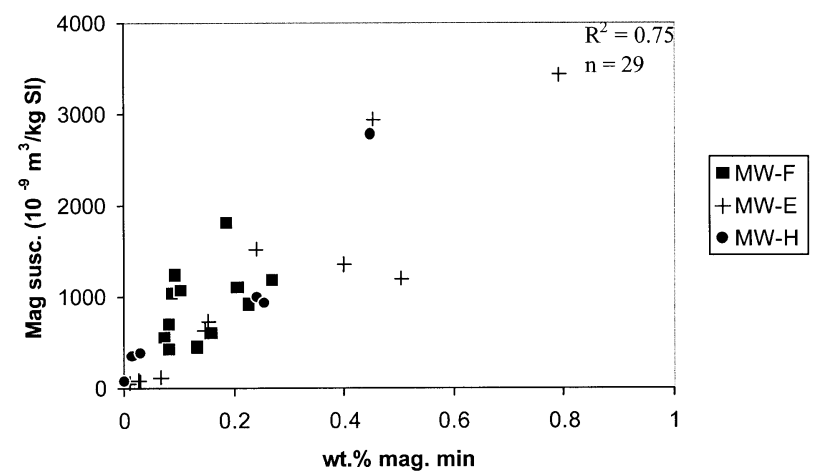

Fig. 8. Comparison of the magnetic susceptibility $\left(\times 10^{-9} \mathrm{SI}\right)$ of the sediment and the concentration of magnetically separated minerals. similar to arsenic levels measured by leaching the bulk sediment in hot acid (mean of $0.7 \mu \mathrm{g} / \mathrm{g}, n=17$; Fig. 9). In contrast, the $\mathrm{Fe}$ content of the magnetic minerals ranged from 20 to 81 $\mathrm{Wt} \%$, which is considerably higher than the concentration of $\mathrm{Fe}$ leachable in hot acid for bulk sediments ranging from 0.3 to 2.1 $\mathrm{Wt} \%$ (average of $1 \mathrm{Wt} \% \mathrm{Fe}, n=17$ ). For comparison, pure magnetite contains $72 \mathrm{Wt} \% \mathrm{Fe}$.

\section{DISCUSSION}

\subsection{Nature of Fe Phases in the Sediment}

The correlation between the redox state of leachable Fe phases of the sediment and the reflectance spectrum of the sediment confirms the connection between the appearance of sandy aquifer particles and the chemical nature of their surface coatings (Fig. 7). This relation appears to be relatively insensitive to changes in background mineralogy from one sample to the other or from one site to the other, including variations in the concentration of dark minerals (Fig. 6D). Comparison of reflectance spectra of either Holocene or Pleistocene sediment with a low leachable $\mathrm{Fe}(\mathrm{II}) / \mathrm{Fe}$ ratio with reference spectra for different $\mathrm{Fe}$ (III) phases, suggests a strong contribution of either hematite, goethite, or ferrihydrite to the coatings (Fig. 10A). The identification of surficial $\mathrm{Fe}$ phases is more ambiguous for sediment with a higher leachable $\mathrm{Fe}(\mathrm{II}) / \mathrm{Fe}$ ratio, in part because the overprint of mineralogy becomes more significant. This is indicated, for instance, by the residual peak in the first derivative transform of the reflectance spectrum at $\sim 520 \mathrm{~nm}$ after $\mathrm{Fe}$ oxyhydroxide coatings have been removed (Fig. 6C). The conversion of $\mathrm{Fe}(\mathrm{III})$ oxyhydroxides to magnetite or siderite under reducing conditions are possibilities since the reference spectra for these solids are relatively flat (Fig. 10B). The 

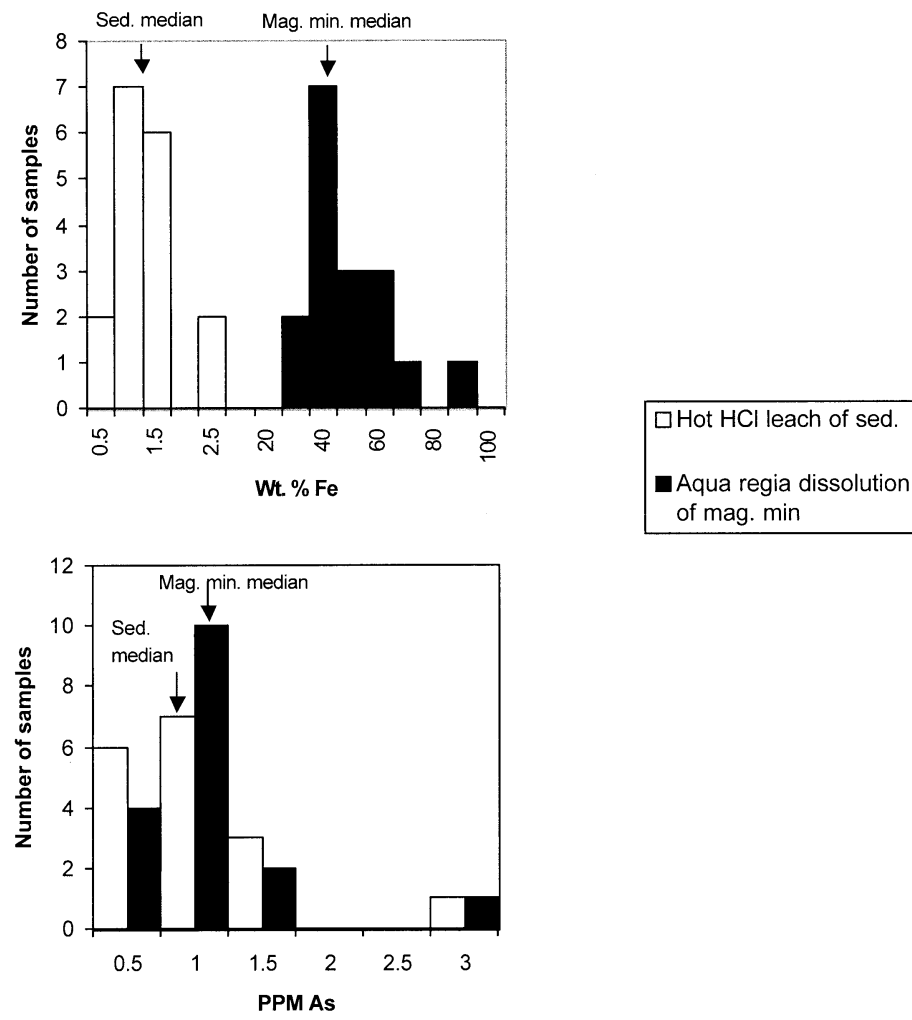

Fig. 9. Histograms of the concentrations of $\mathrm{As}$ and $\mathrm{Fe}$ in the magnetically separated magnetic minerals and the acid-leachable fraction of the sediment at MW-F and MW-E.

potential formation of these solid phases is evaluated in more detail in the following paragraphs.

Magnetite has frequently been observed in laboratory studies as the end product of reduction of $\mathrm{Fe}(\mathrm{III})$ oxyhydroxides by microorganisms (Lovley, 1990; Fredrickson et al., 1998; Benner et al., 2002; Zachara et al., 2002). Pure magnetite is black (Fig. 10B); a growing contribution of magnetite as sediments become more reducing could, therefore, potentially explain the noticeable darkening of the sediment as well as a flattening of the reflectance spectrum. The proportions of $\mathrm{Fe}$ and $\mathrm{O}$ measured in magnetically separated grains by EDX (Fig. 11) is also consistent within $\pm 10 \%$ with the presence of magnetite. On the other hand, the rounded edges observed by SEM (Fig. 11) in the vast majority of the magnetically separated grains suggest extensive abrasion and, therefore, a detrital rather than an authigenic origin.

The dominance of what appears to be detrital magnetite does not exclude the possibility of a minor contribution of authigenic magnetite. Although rare, smaller crystals with sharp edges of the type shown in Figure 11 could have been produced in situ. The formation of a relatively labile authigenic magnetic phase at low temperature is also suggested by the noticeable decline in the strength of magnetic susceptibility maxima at Site TW-5 after gentle heating (data not shown). The generally low susceptibility of Pleistocene sediment is another indication that the magnetic minerals are not impervious to alteration. One possible explanation is that extensive exposure to the atmosphere during a low-stand in sea level led to oxidation of magnetic grains in the sediment. But prolonged reducing conditions within organic-rich sediment could also have led, instead, to the loss of magnetic properties because of reductive dissolution. The available data cannot distinguish the two scenarios.

Since the magnetic grains did not dissolve in hot $\mathrm{HCl}$, the implication is that the presence of detrital magnetite is not the primary cause of the observations of variations in leachable $\mathrm{Fe}(\mathrm{II}) / \mathrm{Fe}$ ratios. This interpretation is consistent with the lack of any obvious connection between spatial patterns in magnetic susceptibility and leachable $\mathrm{Fe}$ (II)/Fe (Fig. 4). Leachable $\mathrm{Fe}(\mathrm{II}) / \mathrm{Fe}$ ratios repeatedly reaching 0.8 in the deeper sandy aquifers of Holocene age indicate, therefore, that there may be a significant pathway of reduction of $\mathrm{Fe}(\mathrm{III})$ oxyhydroxides towards an $\mathrm{Fe}(\mathrm{II})$ phase that dissolves in hot $\mathrm{HCl}$. Siderite $\left(\mathrm{FeCO}_{3}\right)$ and vivianite $\left(\mathrm{Fe}_{3}\left(\mathrm{PO}_{4}\right)_{2}\right)$ are potential candidates because of elevated concentrations of carbonate and phosphate reported for Bangladesh groundwater (BGS and DPHE, 2001; Zheng et al., 2004). Both phases have also been observed during microbial reduction of $\mathrm{Fe}(\mathrm{III})$ oxyhydroxides in the laboratory (Fredrickson et al., 1998; Zachara et al., 1998; Zachara et al., 2002). The relatively low acid-volatile sulfur $(<0.1 \mu \mathrm{mol} / \mathrm{g})$ and total sulfur $(<10 \mu \mathrm{mol} / \mathrm{g})$ content of Bangladesh sediment suggest precipitation with sulfide is not a significant sink for Fe either (Harvey et al., 2002; Swartz et al., in press).

Assuming a dissolved $\mathrm{Fe}(\mathrm{II})$ concentration of $10^{-4} \mathrm{~mol} / \mathrm{L}$ $(\sim 5 \mathrm{mg} / \mathrm{L})$ and a $\mathrm{CO}_{3}^{-2}$ concentration of $10^{-5} \mathrm{~mol} / \mathrm{L}$ at $\mathrm{pH}=7$ (BGS and DPHE, 2001; Zheng et al., 2004), the ion activity product for typical groundwater is two orders of magnitude greater than the solubility product of siderite $\left(\mathrm{pK}_{\mathrm{sp}}=11\right)$ 

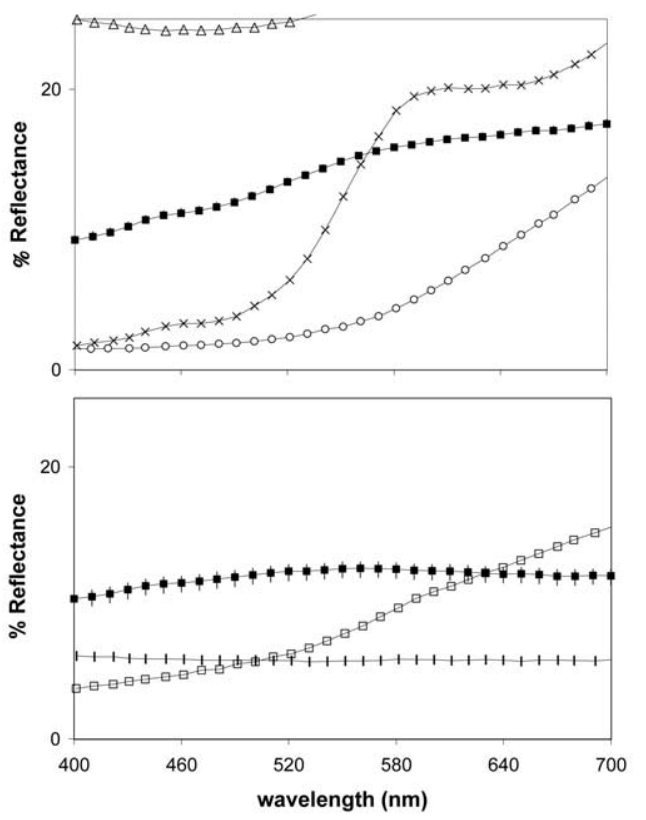
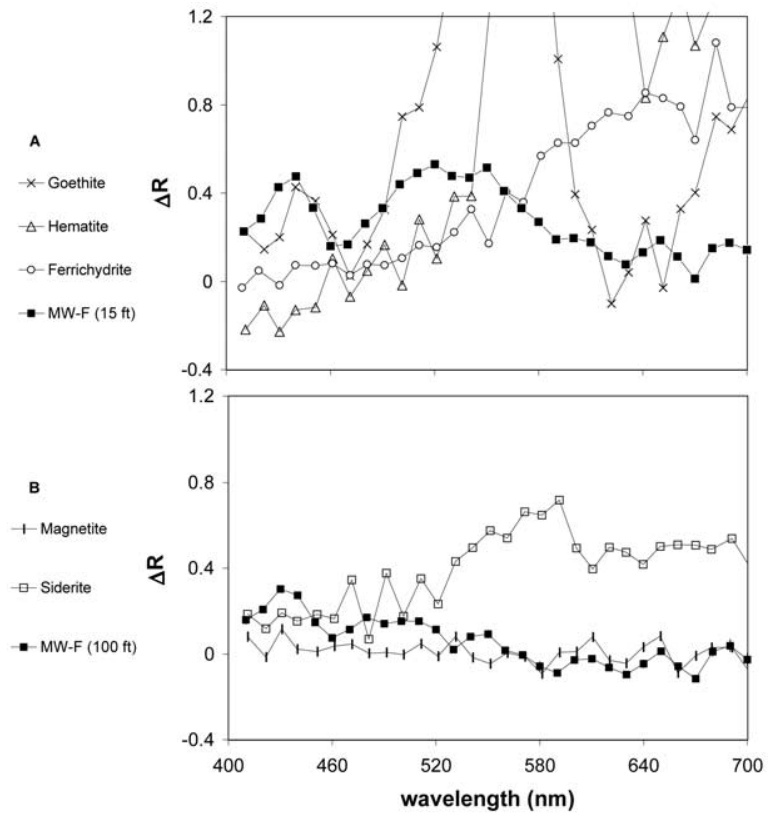

Fig. 10. (A) and (B) Reflectance spectra and their first-derivative transform for a series of $\mathrm{Fe}(\mathrm{III}), \mathrm{Fe}$ (II/III), and $\mathrm{Fe}(\mathrm{II})$ phases (Clark et al., 1993). Also included are spectra for sediment samples from MW-F at $4.5 \mathrm{~m}$ and $30 \mathrm{~m}$, respectively.

(Morel and Hering, 1993). Similarly, the solubility product $\mathrm{pK}_{\mathrm{sp}} \sim 33$ (Morel and Hering, 1993) for vivianite is exceeded by several orders of magnitude for groundwater containing $10^{-4}$ $\mathrm{mol} / \mathrm{L} \mathrm{Fe}(\mathrm{II})$ and $10^{-5} \mathrm{~mol} / \mathrm{L} \mathrm{PO}_{4}^{-3}$. Freshly precipitated siderite and vivianite are white, which seems inconsistent with the observed darkening of the sediment with depth. Incompletely reduced siderite or vivianite is green or blue, on the other hand. These colors were not observed in the sandy aquifer material, but they certainly were in several of the clay layers. It could be that these solids also form in the sandy material, but that their characteristic color is more difficult to observe because of the coarser grain size. The presence of an unstable phase such as green rust (Fredrickson et al., 1998; Zachara et al., 2002) might also have influenced the color of the sediments.

It is worth noting that the total conversion of the typical $1 \mathrm{Wt}$ $\%$ leachable iron to vivanite would require $\sim 1 \mathrm{~mol} / \mathrm{L}^{-3}$, which exceeds typical phosphate concentrations by 5 orders of a magnitude. Complete conversion of $\mathrm{Fe}(\mathrm{III})$ to siderite would require $\sim 1.8 \mathrm{~mol} / \mathrm{L}$ of inorganic carbon, which is a more realistic scenario when compared to levels of $\sim 10 \mathrm{mmol} / \mathrm{L}$ that have been measured (BGS and DPHE, 2001; Harvey et al., 2002). Overall, the precise nature of the phases produced by reduction of $\mathrm{Fe}(\mathrm{III})$ oxyhydroxides remains ambiguous.

\subsection{Mass Balance and Depth Patterns in Redox Conditions}

The depth profiles of leachable Fe(II)/Fe show a clear pattern of conversion of $\mathrm{Fe}$ (III) oxyhydroxides towards $\mathrm{Fe}$ (II) phases with increasing depth. A simple mass balance calculation suggests that this conversion can be driven by the mineralization of organic matter. Assuming a concentration of $1 \%$ by weight of $\mathrm{Fe}(\mathrm{III})$ in the sediment and the unavailability of alternative oxidants, the mineralization of $\sim 0.05 \%$ by weight organic carbon would be sufficient to drive the complete reduction towards $\mathrm{Fe}(\mathrm{II})$ in an aquifer with a $20 \%$ porosity. This is well within the range of organic carbon concentrations measured in sandy sediments of Bangladesh (BGS and DPHE, 2001). Although it is not required to explain the pattern of Fe reduction, additional reducing power contributed to these aquifers in the form of dissolved organic carbon cannot be ruled out (McArthur et al., 2001; Harvey et al., 2002).

While $\mathrm{Fe}(\mathrm{II}) / \mathrm{Fe}$ ratios generally increase with depth, this does not appear to indicate that the transformation of Fe phases linked to the mineralization of organic matter requires thousands of years (Fig. 4). If this had been the case, and assuming the upper aquifers are all of Holocene age, it would be hard to explain the elevated $\mathrm{Fe}(\mathrm{II}) / \mathrm{Fe}$ ratios near the surface at those locations that are capped by an impermeable clay layer. It appears, instead, that the maintenance of relative oxic conditions at those sites where sandy deposits extend to the surface may be maintained by a flux of alternative oxidants from the surface. Assuming an average age of $5000 \mathrm{yr}$ for Holocene sediment and a residence time of groundwater of 10 to $100 \mathrm{yr}$ (Harvey et al., 2002), recharge has probably flushed the shallow aquifers 50 to 500 times since deposition, assuming a $20 \%$ porosity. This is considerably more than the single flushing since deposition estimated by BGS and DPHE (2001). For an initial oxygen concentration of $\sim 20010^{-6} \mathrm{~mol} / \mathrm{L}$ at saturation, this corresponds to an alternative flux of oxidant that could mineralize about one-fifth of $0.05 \mathrm{wt} \%$ organic carbon as $\mathrm{CH}_{2} \mathrm{O}$. The oxidizing power of nitrate corresponding to a typical concentration of $\sim 10^{-5} \mathrm{~mol} / \mathrm{L}$ (Hussam et al., 2003) is small compared to dissolved oxygen. This simple calculation shows that shallow recharge could inhibit the reduction of $\mathrm{Fe}$ (III) oxyhydroxides. By the same token, a reduction in the flux of oxidants by one to two orders of magnitude below an 


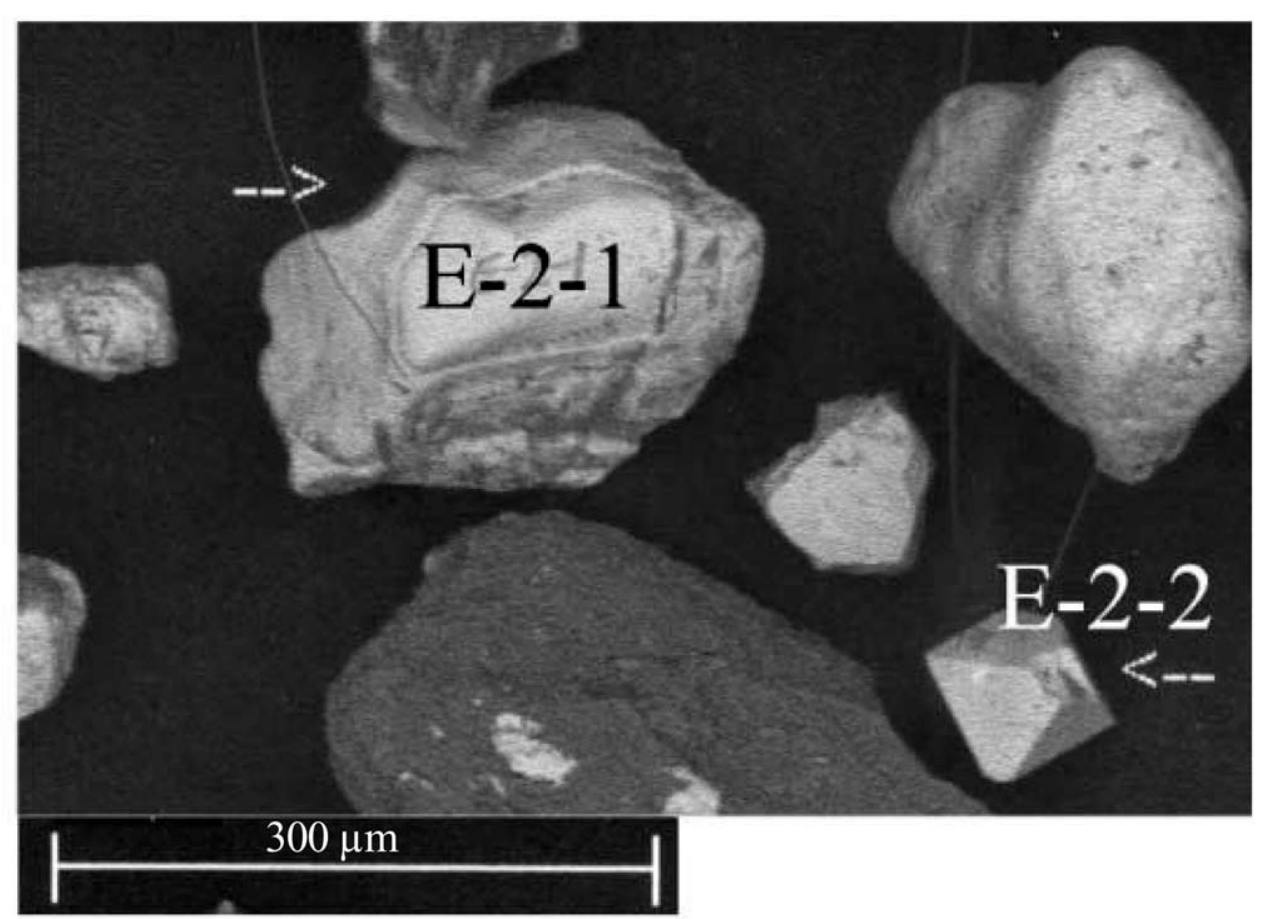

\begin{tabular}{|l|l|l|l|l|l|l|l|l|l|l|l|l|}
\hline Wt\%/sample & $\mathrm{O}$ & $\mathrm{Na}$ & $\mathrm{Mg}$ & $\mathrm{Alk}$ & $\mathrm{Si}$ & $\mathrm{K}$ & $\mathrm{Ca}$ & $\mathrm{Ti}$ & $\mathrm{V}$ & $\mathrm{Mn}$ & $\mathrm{Fe}$ & sum \\
\hline E-2-1 & $\mathbf{2 8 . 7}$ & $\mathbf{0 . 5}$ & $\mathbf{0 . 4}$ & $\mathbf{0 . 5}$ & $\mathbf{3 . 8}$ & & $\mathbf{1 . 3}$ & $\mathbf{0 . 3}$ & & & $\mathbf{6 4 . 5}$ & $\mathbf{1 0 0 . 0}$ \\
\hline E-2-2 & $\mathbf{1 2 . 1}$ & $\mathbf{0 . 2}$ & $\mathbf{0 . 2}$ & $\mathbf{0 . 7}$ & $\mathbf{1 . 0}$ & $\mathbf{0 . 3}$ & $\mathbf{0 . 2}$ & $\mathbf{1 . 6}$ & $\mathbf{0 . 4}$ & $\mathbf{1 . 3}$ & $\mathbf{8 2 . 1}$ & $\mathbf{1 0 0 . 0}$ \\
\hline
\end{tabular}

Fig. 11. SEM image of representative magnetic minerals separated from the sediment at MW-E at a depth of 9 m. EDX results are also shown for the two grains marked by arrows on the SEM image.

impermeable clay layer could lead to extensive Fe reduction close to the surface. The surficial clay layers observed at MW-H and TW-5 could, therefore, explain the shallow onset of reducing conditions at these sites indicated by $\mathrm{Fe}(\mathrm{II}) / \mathrm{Fe}$ (Fig. 4B).

If flushing of the shallow aquifers occurs on timescales of decades to centuries, could the loss of Fe from the sediment indicated by elevated $\mathrm{Fe}$ (II) concentrations in groundwater leave an imprint on the Fe content of the sediment? Using the same assumptions used above to estimate the supply of oxygen and nitrate, the loss of Fe corresponding to a steady concentration of $5 \mathrm{mg} / \mathrm{L}$ would be equivalent to a 0.25 to $2.5 \%$ loss of $\mathrm{Fe}$ from the sediment. This is within the range of leachable or reducible $\mathrm{Fe}$ concentrations measured in Bangladesh aquifer material (BGS and DPHE, 2001; van Geen et al., this volume), and suggests that such a loss might be significant but difficult to detect in the solid phase.

\subsection{Redox Conditions and As Concentrations in Groundwater}

The spatial distributions of groundwater As and the redox state of the sediment suggest that the two properties are related. Dissolved As concentrations typically increase with depth, and so does the $\mathrm{Fe}(\mathrm{II}) / \mathrm{Fe}$ ratio in the leachable Fe fraction of the sediment (Fig. 4). Among sites as well, the ranking of average As concentrations in surrounding wells follows the overall trend of $\mathrm{Fe}(\mathrm{II}) / \mathrm{Fe}$ in the sediment. At the same time, dissolved Fe concentrations are not significantly different from one site to the other. The release of As, corresponding to a $5 \mathrm{mg} / \mathrm{L}$ increase in dissolved $\mathrm{Fe}$ at the average $\mathrm{As} / \mathrm{Fe}$ mass ratio of 7 $* 10^{-5}$ measured in the acid-leachable fraction, corresponds to only a $0.4 \mu \mathrm{g} / \mathrm{L}$ increase in dissolved As, as pointed out also by BGS and DPHE (2001). This suggests that the processes that mobilize As and $\mathrm{Fe}$ are decoupled, possibly because Fe reprecipitates following the reduction of $\mathrm{Fe}$ (III) oxyhydroxides while the liberated As remains in solution. This is essentially what was observed during the incubation experiments described in the companion paper by van Geen et al. (this volume).

Elevated As concentrations in groundwater are much easier to explain if estimates of mobilization are based on conversions within the solid phase rather than the actual release of $\mathrm{Fe}(\mathrm{II})$ to groundwater. If the conversion of $1 \%$ by weight $\mathrm{Fe}$ (III) to a reduced phase is assumed to entirely mobilize As under the previous assumption that an aquifer is flushed 50 to 500 times, the corresponding increase in dissolved As would range from 
20 to $200 \mu \mathrm{g} / \mathrm{L}$, which is consistent with the observations. It is worth pointing out in this context that although much of the magnetite in the aquifer material is probably of detrital origin, the two orders of magnitude lower $\mathrm{As} / \mathrm{Fe}$ ratio in magnetite relative to the leachable $\mathrm{Fe}$ fraction of the bulk sediment supports the notion that As might be excluded from the new lattice formed upon partial reduction of $\mathrm{Fe}(\mathrm{III})$ to magnetite (van Geen et al., this volume).

There appears to be a threshold in sediment redox conditions that can be used to predict whether associated groundwater As concentrations are likely to be low. None of the monitoring wells that extend to sandy material with $\mathrm{Fe}(\mathrm{II}) / \mathrm{Fe}$ ratios below 0.4 yield groundwater with As concentrations above $10 \mu \mathrm{g} / \mathrm{L}$ (Fig. 5B). The corresponding $\Delta \mathrm{R}$ values of the first derivative transform of the reflectance of the same sediment samples are all above 0.6 (Fig. 5C). This suggests that groundwater As concentrations may be kept in check by some minimum proportion of $\mathrm{Fe}(\mathrm{III})$ oxyhydroxides present on the surface of aquifer particles. This observation is also consistent with the parallel incubation experiments showing that As is not released to solution from sediment containing all or some Fe(III) oxyhydroxides, unless dissolution is promoted by the addition of a source of reduced carbon (van Geen et al., this volume). If a similar predictive threshold holds throughout Bangladesh, this indicator might eventually prove to be useful for drilling wells, an activity that continues unabated. While the human eye can certainly see the difference between gray Holocene sediment and orange Pleistocene material, a low-cost device that compares reflectance at two wavelengths on either side of $520 \mathrm{~nm}$ could be used to distinguish different shades of gray within more recent deposits (Kostel, 2002).

\section{CONCLUSION}

Although the spatial distributions of As in groundwater and the oxidation state of the leachable Fe fraction of the sediment are clearly connected, the relatively low Fe-concentrations in groundwater suggest a process that is more complex than congruent dissolution. Release of As to groundwater is consistent with release by reduction of $\mathrm{Fe}$ oxyhydroxide coatings, while most of the Fe is retained on the solid phase. The changes in the reflectance spectrum of the sediment that were documented are consistent with variations in the oxidation state of the leachable Fe fraction, although the Fe(II) phases that are formed could not be identified with certainty. If the transformation yields authigenic magnetite, this component is hidden by a significant contribution of detrital magnetite. The formation of $\mathrm{Fe}$ (II) or $\mathrm{Fe}(\mathrm{II} / \mathrm{III})$ phases that leave As in solution could help explain the significant scatter in the relationship between dissolved As and $\mathrm{Fe}$ concentrations in Bangladesh groundwater. The identification of a threshold in redox conditions that prevents the release of As to groundwater might help drillers target aquifers that are low in As.

Acknowledgments-This study was supported by grant P42ES10349 of the US NIEHS/Superfund Basic Research Program. We thank J. Ortiz (Kent State University) for showing us how to make reflectance measurements and D. Breger for running the SEM facility at LDEO. This is Lamont-Doherty contribution number 6583.

Associate editor: G. Sposito

\section{REFERENCES}

Aggett J. and Obrien G. A. (1985) Detailed model for the mobility of arsenic in lacustrine sediments based on measurements in Lake Ohakuri. Environmental Science \& Technology 19, 231-238.

Balsam W. L. and Deaton B. C. (1991) Sediment dispersal in the Atlantic-Ocean - evaluation by visible-light spectra. Reviews in Aquatic Sciences 4, 411-447.

Balsam W. L. and Wolhart R. J. (1993) Sediment dispersal in the Argentine Basin - evidence from visible-light spectra. Deep-Sea Research Part II-Topical Studies in Oceanography 40, 1001-1031.

Belzile N. and Tessier A. (1990) Interactions between arsenic and iron oxyhydroxides in lacustrine sediments. Geochim. Cosmochim. Acta 54, 103-109.

Benner S. G., Hansel C. M., Wielinga B. W., Barber T. M., and Fendorf S. (2002) Reductive dissolution and biomineralization of iron hydroxide under dynamic flow conditions. Environmental Science \& Technology 36, 1705-1711.

BGS and DPHE (2001) Arsenic contamination of groundwater in Bangladesh (ed. D. G. Kinniburgh and P. L. Smedley) British Geological Survey.

Bowell R. J. (1994) Sorption of arsenic by iron-oxides and oxyhydroxides in soils. Applied Geochemistry 9, 279-286.

Bradley P. M., Chapelle F. H., and Lovley D. R. (1998) Humic acids as electron acceptors for anaerobic microbial oxidation of vinyl chloride and dichloroethene. Applied and Environmental Microbiology 64, 3102-3105.

Caccavo F., Lonergan D. J., Lovley D. R., Davis M., Stolz J. F., and Mcinerney M. J. (1994) Geobacter Sulfurreducens Sp-Nov, a Hydrogen-Oxidizing and Acetate-Oxidizing Dissimilatory Metal-Reducing Microorganism. Applied and Environmental Microbiology 60, 3752-3759.

Clark R. N., Swayze G. A., Gallagher A. J., King T. V. V. and Calvin W. M. (1993) The U.S. Geological Survey, Digital Spectral Library: Version $1(0.2$ to $3 \mu \mathrm{m})$, pp. 1326, U.S. Geological Survey.

Clark R. N. (1999) Chapter 1: Spectroscopy of rocks and minerals, and principles of spectroscopy. In Manual of Remote Sensing, Volume 3, Remote Sensing for the Earth Sciences (ed. A. N. Rencz). John Wiley and Sons, New York, p. 3-58.

Cummings D. E., Caccavo F., Fendorf S., and Rosenzweig R. F. (1999) Arsenic mobilization by the dissimilatory $\mathrm{Fe}(\mathrm{III})$-reducing bacterium Shewanella alga BrY. Environmental Science \& Technology 33, 723-729.

Cummings D. E., March A. W., Bostick B., Spring S., Caccavo F., Fendorf S., and Rosenzweig R. F. (2000) Evidence for microbial $\mathrm{Fe}(\mathrm{III})$ reduction in anoxic, mining-impacted lake sediments (Lake Coeur d'Alene, Idaho). Applied and Environmental Microbiology 66, 154-162.

Dhar R. K., Biswas B. K., Samanta G., Mandal B. K., Chakraborti D., Roy S., Jafar A., Islam A., Ara G., Kabir S., Khan A. W., Ahmed S. A., and Hadi S. A. (1997) Groundwater arsenic calamity in Bangladesh. Current Science 73, 48-59.

Evans M. E. and Heller F. (2003) Environmental Magnetism. Academic Press.

Fergusson J. (1863) On recent changes in the delta of the Ganges. Quarterly J. of the Geol. Society 19, 321-354.

Fredrickson J. K., Zachara J. M., Kennedy D. W., Dong H. L., Onstott T. C., Hinman N. W., and Li S. M. (1998) Biogenic iron mineralization accompanying the dissimilatory reduction of hydrous ferric oxide by a groundwater bacterium. Geochim. Cosmochim. Acta 62, 3239-3257.

Giosan L., Flood R. D., and Aller R. C. (2002) Paleoceanographic significance of sediment color on western North Atlantic drifts: I. Origin of color. Marine Geol. 189, 25-41.

Goodbred S. L. and Kuehl S. A. (1999) Holocene and modern sediment budgets for the Ganges-Brahmaputra river system: Evidence for highstand dispersal to flood-plain, shelf, and deep-sea depocenters. Geol. 27, 559-562.

Goodbred S. L. and Kuehl S. A. (2000) The significance of large sediment supply, active tectonism, and eustasy on margin sequence development: Late Quaternary stratigraphy and evolution of the Ganges-Brahmaputra delta. Sedimentary Geol. 133, 227-248. 
Goodbred S. L., Kuehl S. A., Steckler M. S., and Sarker M. H. (2003) Controls on facies distribution and stratigraphic preservation in the Ganges-Brahmaputra delta sequence. Sedimentary Geol. 155, 301316.

Harvey C. F., Swartz C. H., Baruzzaman A. B. M., Keon-Blute N., Yu W., Ali A., Jay J., Beckie R., Niedan V., Brabander D., Oates P. M., Ashfaque K. N., Islam S., Hemond H. F., and Ahmed M. F. (2002) Arsenic mobility and groundwater extraction in Bangladesh. Science 298, 1602-1606.

Hussam A., Habibuddowla M., Alauddin M., Hossain Z. A., Munir A. K. M., and Khan A. H. (2003) Chemical fate of arsenic and other metals in groundwater of Bangladesh: Experimental measurement and chemical equilibrium model. J. of Environmental Science and Health Part a-Toxic/Hazardous Substances \& Environmental Engineering 38, 71-86.

Kostel K. (2002) A simple sediment color meter to target low-arsenic aquifers in Bangladesh. Masters Thesis, Columbia University.

Lloyd J. R., Sole V. A., Van Praagh C. V. G., and Lovley D. R. (2000) Direct and $\mathrm{Fe}$ (II)-mediated reduction of technetium by $\mathrm{Fe}$ (III)-reducing bacteria. Applied and Environmental Microbiology 66, 37433749 .

Lord C. J., III.. (1982) A selective and precise method for pyrite determination in sedimentary materials. J. of Sedimentary Petrology 52, 664-666.

Lovley D. R. (1990) Magnetite Formation During Microbial Dissimilatory Iron Reduction. Plenum Publishing Corporation.

Lovley D. R. (1997) Microbial Fe(III) reduction in subsurface environments. FEMS Microbiology Reviews 20, 305-313.

McArthur J. M., Ravenscroft P., Safiulla S., and Thirlwall M. F. (2001) Arsenic in groundwater: Testing pollution mechanisms for sedimentary aquifers in Bangladesh. Water Resources Research 37, 109117.

Morel F. M. M. and Hering J. G. (1993) Principles and Applications of Aquatic Chemistry. John Wiley and Sons.

Nevin K. P. and Lovley D. R. (2002a) Mechanisms for accessing insoluble $\mathrm{Fe}(\mathrm{III})$ oxide during dissimilatory $\mathrm{Fe}(\mathrm{III})$ reduction by Geothrix fermentans. Applied and Environmental Microbiology 68, 2294-2299.

Nevin K. P. and Lovley D. R. (2002b) Mechanisms for Fe(III) oxide reduction in sedimentary environments. Geomicrobiology J. 19, 141-159.

Nickson R., McArthur J., Burgess W., Ahmed K. M., Ravenscroft P., and Rahman M. (1998) Arsenic poisoning of Bangladesh groundwater. Nature 395, 338.

Nickson R. T., McArthur J. M., Ravenscroft P., Burgess W. G., and Ahmed K. M. (2000) Mechanism of arsenic release to groundwater, Bangladesh and West Bengal. Applied Geochemistry 15, 403-413.

Niggemyer A., Spring S., Stackebrandt E., and Rosenzweig R. F. (2001) Isolation and characterization of a novel As(V)-reducing bacterium: Implications for arsenic mobilization and the genus Des- ulfitobacterium. Applied and Environmental Microbiology 67, $5568-5580$.

Peterson M. L. and Carpenter R. (1986) Arsenic distributions in porewaters and sediments of Puget-Sound, Lake Washington, the Washington Coast and Saanich Inlet, BC. Geochim. Cosmochim. Acta 50, 353-369.

Smith A. H., Lingas E. O., and Rahman M. (2000) Contamination of drinking-water by arsenic in Bangladesh: a public health emergency. Bulletin World Health Organization 78, 1093-1103.

Sullivan K. A. and Aller R. C. (1996) Diagenetic cycling of arsenic in Amazon shelf sediments. Geochim. Cosmochim. Acta 60, 14651477.

Swartz C. H., Blute N. K., Badruzzman B., Ali A., Brabander D., Jay J., Besancon J., Islam S. A. and Hemond H. F. (In press) Mobility of arsenic in a Bangladesh aquifer: inferences from geochemical profiles, leaching data and mineralogical characterization. Geochim. Cosmochim. Acta.

van Geen A., Zheng Y., Versteeg R., Stute M., Horneman A., Dhar R. Steckler M., Gelman A., Small C., Ahsan H., Graziano J., Hussein I. and Ahmed K. M. (2003) Spatial variability of arsenic in 6000 tube wells in a $25 \mathrm{~km}^{2}$ area of Bangladesh. Water Resources Research 35(5), 1140-1155.

van Geen A., Rose J., Thoral S., Garnier J. M., Zheng Y. and Bottero J. Y. Decoupling of As and Fe release to Bangladesh groundwater under reducing conditions. Part II: Evidence from sediment incubations. Geochim. Cosmochim. Acta 68(16).

Viollier E., Inglett P. W., Hunter K., Roychoudhury A. N., and Van Cappellen P. (2000) The ferrozine method revisited: $\mathrm{Fe}(\mathrm{II}) / \mathrm{Fe}(\mathrm{III})$ determination in natural waters. Applied Geochemistry 15, 785-790.

Welch A. H., Westjohn D. B., Helsel D. R., and Wanty R. B. (2000) Arsenic in ground water of the United States: Occurrence and geochemistry. Ground Water 38, 589-604.

Widerlund A. and Ingri J. (1995) Early diagenesis of arsenic in sediments of the Kalix-River Estuary, Northern Sweden. Chem. Geol. 125, 185-196.

Yu W. H., Harvey C. M. and Harvey C. F. (2003) Arsenic in groundwater in Bangladesh: A geostatistical and epidemiological framework for evaluating health effects and potential remedies. Water Resources Research 39(5), 695-704.

Zachara J. M., Fredrickson J. K., Li S. M., Kennedy D. W., Smith S. C., and Gassman P. L. (1998) Bacterial reduction of crystalline Fe3+ oxides in single phase suspensions and subsurface materials. American Mineralogist 83, 1426-1443.

Zachara J. M., Kukkadapu R. K., Fredrickson J. K., Gorby Y. A., and Smith S. C. (2002) Biomineralization of poorly crystalline Fe(III) oxides by dissimilatory metal reducing bacteria (DMRB). Geomicrobiology J. 19, 179-207.

Zheng Y., Stute M., van Geen A., Gavrieli I., Dhar R., Simpson H. J., Schlosser P., and Ahmed. K. M. (2004) Redox control of arsenic mobilization in Bangladesh groundwater. Applied Geochemistry 19, 201-214. 